\title{
Buried Waste Integrated Demonstration FY-95 Deployment: Plan
}

\author{
D. E. Stacey
}

Published March 1995

\section{Idaho National Engineering Laboratory Lockheed Idaho Technologies Company Idaho Falls, Idaho 83415}




\section{DISCLAIMER}

This report was prepared as an account of work sponsored by an agency of the United States Government. Neither the United States Government nor any agency thereof, nor any of their employees, make any warranty, express or implied, or assumes any legal liability or responsibility for the accuracy, completeness, or usefulriess of any information, apparatus, product, or process disclosed, or represents that its use would not infringe privately owned rights. Reference herein to any specific commercial product, process, or service by trade name, trademark, manufacturer, or otherwise does not necessarily constitute or imply its endorsement, recommendation, or favoring by the United States Government or any agency thereof. The views and opinions of authors expressed herein do not necessarily state or reflect those of the United States Government or any agency thereof. 


\section{DISCLAIMER}

Portions of this document may be illegible in electronic image products. Images are produced from the best available original document. 


\section{Buried Waste Integrated Demonstration FY-95 Deployment Plan}

INEL-95/0089

Prepared by:
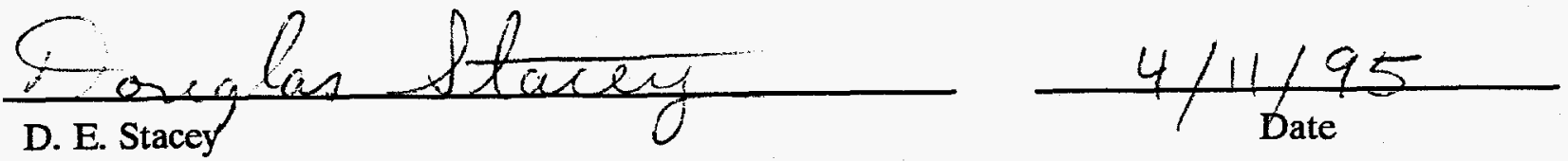

Engineer

Reviewed by:
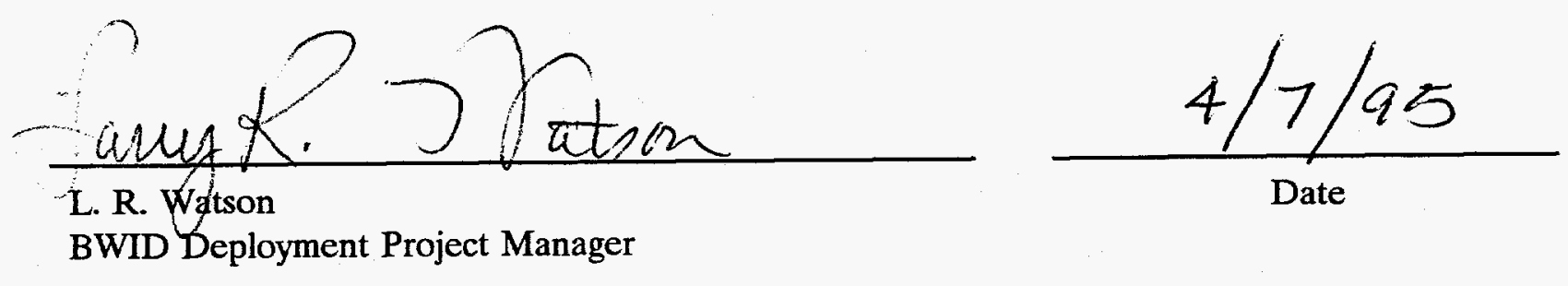

Approved by:

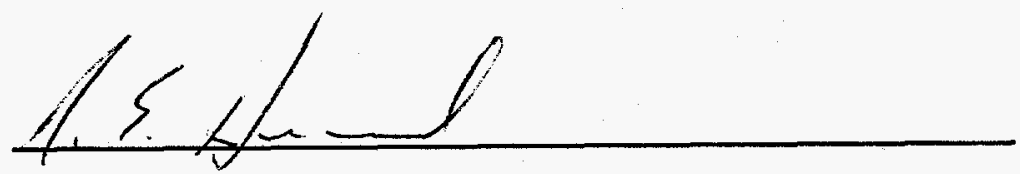

R. E. Heard

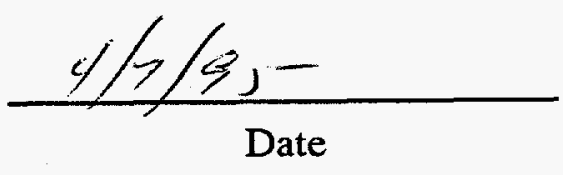




\section{ABSTRACT}

The Buried Waste Integrated Demonstration (BWID) is a program funded by the U.S. Department of Energy Office of Technology Development. BWID supports the applied research, development, demonstration, testing, and evaluation of a suite of advanced technologies that together form a comprehensive remediation system for the effective and efficient remediation of buried waste.

The FY-95 effort will fund 24 technologies in five areas of buried waste site remediation: site characterization, waste characterization, retrieval, treatment, and containment/stabilization. Ten of these technologies will take part in the integrated field demonstration that will take place at the Idaho National Engineering Laboratory (INEL) facilities in the summer of 1995.

This document is the basic operational planning document for deployment of all BWID projects funded in FY-95. Discussed in this document are the BWID preparations for the INEL integrated field demonstration, INEL research and development (R\&D) demonstrations, non-INEL R\&D demonstrations, and office research and technical review meetings. Each project will have a test plan detailing the specific procedures, objectives, and tasks of the test. Therefore, information that is specific to testing each technology is intentionally limited in this document. 


\section{SUMMARY}

The Buried Waste Integrated Demonstration (BWID) program supports the applied research, development, demonstration, testing, and evaluation of a suite of technologies that, when integrated with commercially available baseline technologies, form a comprehensive system for the effective and efficient remediation of buried waste throughout the U.S. Department of Energy complex.

The FY-95 effort will deploy 10 field technologies in an integrated field demonstration at the Idaho National Engineering Laboratory (INEL). Four of these technologies will be deployed at the North Boulevard Robotics Complex (NBRC). These technologies include Imaging Infrared Interferometer, Cooperative Telerobotic Retrieval, High Resolution Imaging of Buried Waste Using Holographic Impulse Radar Assay, and Hot Spot Retrieval/Conveyance Demonstration. The remaining six technologies will be deployed at other INEL facilities and include Nonintrusive Sensing of Environmentally Important Objects and Species; Real-Time Monitoring of Transuranic Contaminated Dust; 3-D Dynamic Graphic Simulation of Retrieval Configuration Options; Innovative Grout Demonstration; BWID Graphite DC Arc Plasma; and Excavated Waste Assay.

Other demonstrations to be performed at the INEL as research and development (R\&D) demonstrations include Prompt Gamma Neutron Activation Analysis for Solving Waste Assay Problems, BWID Digface Characterization, Virtual Environment: Applications to Buried Waste, Cryogenic Cutting System, and Machine Performance Monitoring and Prediction.

Additional R\&D demonstrations are planned at non-INEL facilities, such as other government facilities, university laboratories, and vendor sites. The non-INEL projects include High Speed Digital Radiography and Computed Tomography of Waste Drums, Improved TRU Waste Assay: CTEN, Nondestructive Assay Characterization Using Active and Passive Computed Tomography, Very Early Time Electromagnetics, Secondary Treatment of BWID Off-Gas Using Nonthermal Plasma, and Correlation of Metal Volatility Test to BWID and INEL Pit 9 Tests.

The remaining BWID projects consist of office research (paper studies and computer simulations) and technical review meetings. The following projects fall into this category: Radiological and Hazardous Material Measurement System, Site Characterization and Ground Penetrating Radar Consortium, and Treatment R\&D/Performance Testing.

This document defines the requirements for the demonstrations to be conducted in the field in FY-95. Technologies to be demonstrated in the field in FY-96 or beyond are not considered in this document. The basic requirements to support the demonstrations of other technologies are also presented, but more briefly. Requirements such as safety and environmental protection are currently defined by facility managers and organizations responsible for the facilities in which the work will be performed. However, BWID is responsible for defining requirements for the INEL Cold Test Pit and the NBRC.

During FY-95, it is anticipated that changes to the planned activities may occur. Each of these changes will be reviewed by the BWID Deployment Team to determine the necessary modifications to the planned activities as well as to this document. 



\section{CONTENTS}

ABSTRACT $\ldots \ldots \ldots \ldots \ldots \ldots \ldots \ldots \ldots \ldots \ldots \ldots \ldots \ldots \ldots \ldots \ldots \ldots \ldots \ldots \ldots$

SUMMARY $\ldots \ldots \ldots \ldots \ldots \ldots \ldots \ldots \ldots \ldots \ldots \ldots \ldots \ldots \ldots \ldots \ldots \ldots$

ACRONYMS $\ldots \ldots \ldots \ldots \ldots \ldots \ldots \ldots \ldots \ldots \ldots \ldots \ldots \ldots \ldots \ldots \ldots \ldots \ldots$

1. INTRODUCTION $\ldots \ldots \ldots \ldots \ldots \ldots \ldots \ldots \ldots \ldots \ldots \ldots \ldots \ldots \ldots \ldots$

1.1 Purpose and Scope $\ldots \ldots \ldots \ldots \ldots \ldots \ldots \ldots \ldots \ldots \ldots \ldots \ldots \ldots$

1.2 Historical Perspective $\ldots \ldots \ldots \ldots \ldots \ldots \ldots \ldots \ldots \ldots \ldots \ldots \ldots \ldots \ldots$

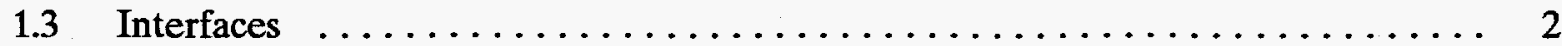

1.4 Technology Descriptions $\ldots \ldots \ldots \ldots \ldots \ldots \ldots \ldots \ldots \ldots \ldots \ldots \ldots \ldots$

1.4.1 INEL Integrated Field Demonstration $\ldots \ldots \ldots \ldots \ldots \ldots \ldots \ldots \ldots$

1.4.2 Research and Development Technologies ................ 8

2. ORGANIZATION AND RESPONSIBILITIES $\ldots \ldots \ldots \ldots \ldots \ldots \ldots \ldots \ldots \ldots$

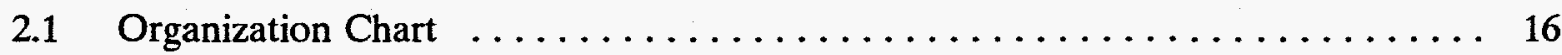

2.2 Personnel Responsibilities $\ldots \ldots \ldots \ldots \ldots \ldots \ldots \ldots \ldots \ldots \ldots \ldots \ldots \ldots$

2.2.1 Project/Cost Account Manager $\ldots \ldots \ldots \ldots \ldots \ldots \ldots \ldots \ldots \ldots$

2.2.2 Integrated Demonstration Coordinator $\ldots \ldots \ldots \ldots \ldots \ldots \ldots \ldots$

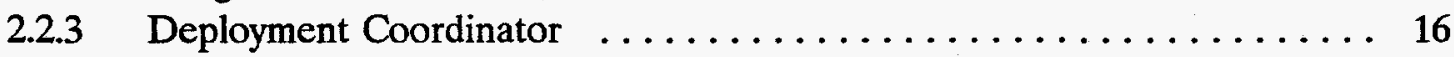

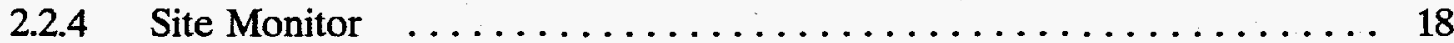

3. ESH\&Q BWID DEPLOYMENT SUPPORT $\ldots \ldots \ldots \ldots \ldots \ldots \ldots \ldots \ldots \ldots \ldots$

3.1 Description of BWID ESH\&Q Deployment Support $\ldots \ldots \ldots \ldots \ldots \ldots$

3.2 Environmental Documentation $\ldots \ldots \ldots \ldots \ldots \ldots \ldots \ldots \ldots \ldots \ldots$

3.2.1 National Environmental Policy Act Documentation ............ 19

3.2.2 Storm Water Pollution Prevention Plans $\ldots \ldots \ldots \ldots \ldots \ldots \ldots$

3.2.3 Archaeological Surveys . . . . . . . . . . . . . . . . . 19

3.2.4 Threatened and Endangered Species Surveys .............. 20

$3.3 \quad$ Hazard Classifications $\ldots \ldots \ldots \ldots \ldots \ldots \ldots \ldots \ldots \ldots \ldots \ldots \ldots \ldots$

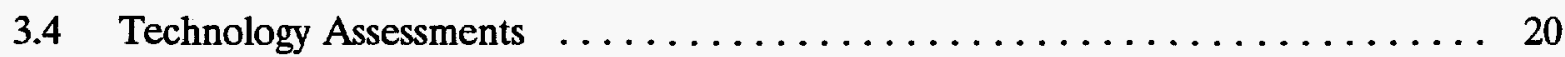




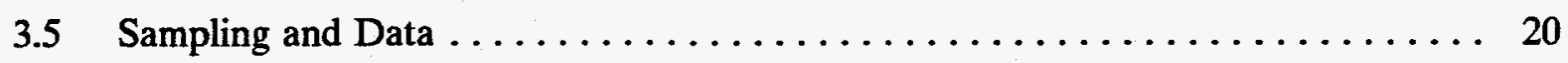

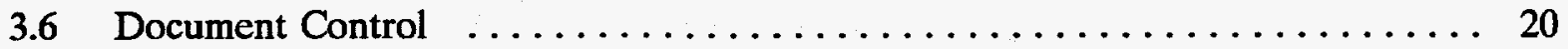

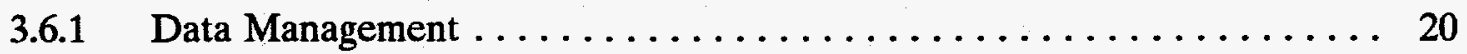

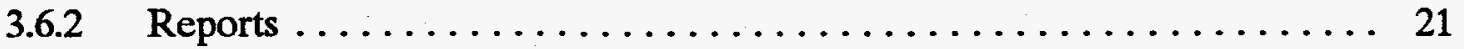

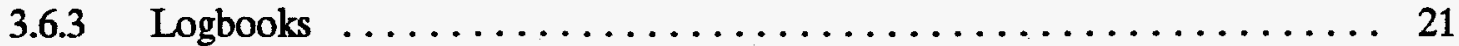

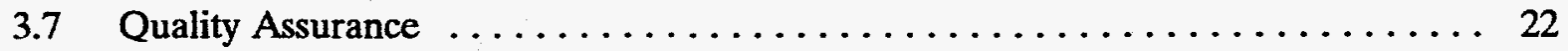

3.7.1 Internal Quality Control Checks $\ldots \ldots \ldots \ldots \ldots \ldots \ldots \ldots \ldots 22$

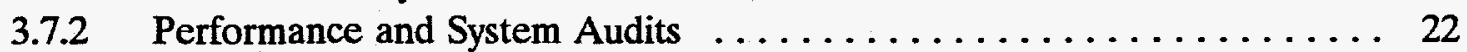

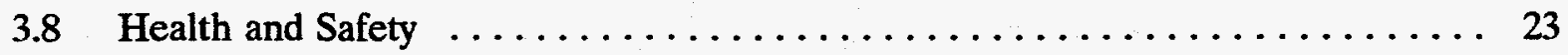

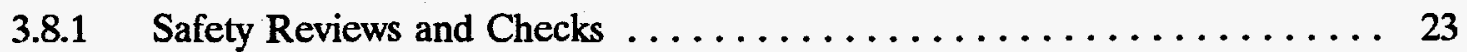

3.8.2 Safe Work Permits ......................... 23

3.9 Residuals Management and Waste Minimization $\ldots \ldots \ldots \ldots \ldots \ldots \ldots .23$

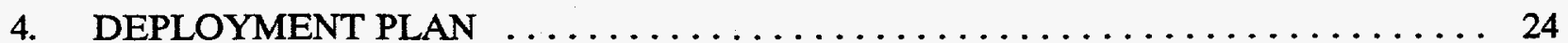

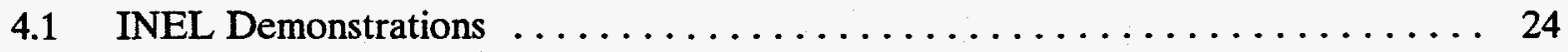

4.1.1 INEL Field Demonstrations $\ldots \ldots \ldots \ldots \ldots \ldots \ldots \ldots \ldots \ldots \ldots$

4.1.2 INEL Laboratory Demonstrations $\ldots \ldots \ldots \ldots \ldots \ldots \ldots \ldots \ldots$

4.2 Non-INEL R\&D Demonstrations $\ldots \ldots \ldots \ldots \ldots \ldots \ldots \ldots \ldots \ldots \ldots \ldots \ldots$

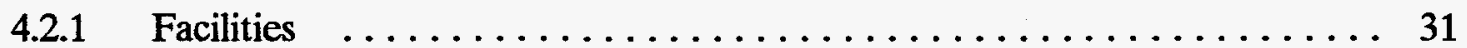

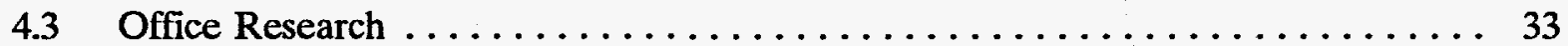

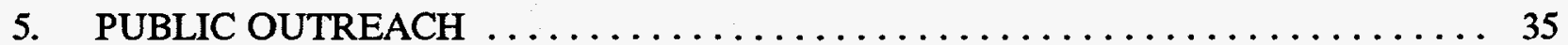

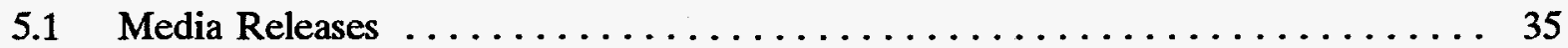

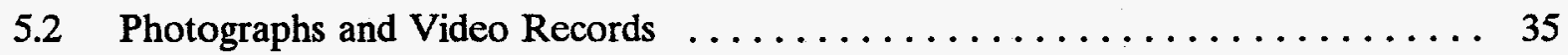

5.3 Open House and Equipment Display $\ldots \ldots \ldots \ldots \ldots \ldots \ldots \ldots \ldots \ldots \ldots$

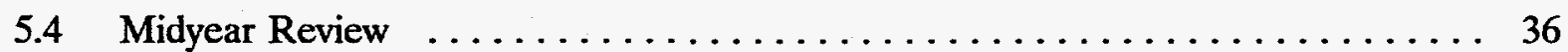

6. SCHEDULES $\ldots \ldots \ldots \ldots \ldots \ldots \ldots \ldots \ldots \ldots \ldots \ldots \ldots \ldots \ldots \ldots \ldots \ldots \ldots \ldots \ldots$

6.1 BWID Deployment Team Activities Schedule $\ldots \ldots \ldots \ldots \ldots \ldots \ldots \ldots$ 
6.2 Technology Test Schedule $\ldots \ldots \ldots \ldots \ldots \ldots \ldots \ldots \ldots \ldots \ldots \ldots \ldots \ldots$

6.2.1 INEL Integrated Field Demonstration Test Schedule $\ldots \ldots \ldots \ldots \ldots . \ldots 37$

6.2.2 INEL R\&D Test Schedule $\ldots \ldots \ldots \ldots \ldots \ldots \ldots \ldots \ldots \ldots \ldots \ldots \ldots \ldots \ldots$

$6.2 .3 \quad$ Non-INEL $R \& D$ Test Schedule $\ldots \ldots \ldots \ldots \ldots \ldots \ldots \ldots \ldots \ldots$

FIGURES

1. BWID organizational structure $\ldots \ldots \ldots \ldots \ldots \ldots \ldots \ldots \ldots \ldots \ldots \ldots \ldots$

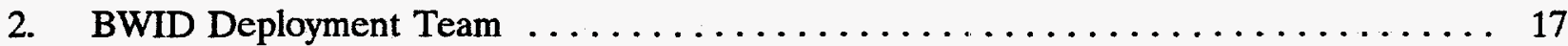

3. INEL integrated field demonstration technologies $\ldots \ldots \ldots \ldots \ldots \ldots \ldots \ldots$

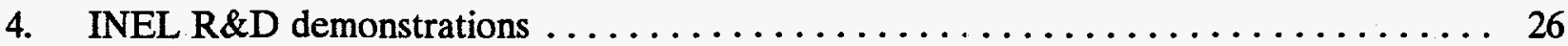

5. Non-INEL R\&D demonstrations $\ldots \ldots \ldots \ldots \ldots \ldots \ldots \ldots \ldots \ldots \ldots \ldots \ldots \ldots$

6. Office research $\ldots \ldots \ldots \ldots \ldots \ldots \ldots \ldots \ldots \ldots \ldots \ldots \ldots \ldots \ldots \ldots \ldots$

7. Deployment Team activities schedule $\ldots \ldots \ldots \ldots \ldots \ldots \ldots \ldots \ldots \ldots \ldots \ldots$

8. Schedules of INEL integrated field demonstration technologies $\ldots \ldots \ldots \ldots \ldots$

9. Schedules for INEL $R \& D$ technologies $\ldots \ldots \ldots \ldots \ldots \ldots \ldots \ldots \ldots \ldots$

10. Schedules for non-INEL $R \& D$ technologies $\ldots \ldots \ldots \ldots \ldots \ldots \ldots \ldots \ldots$

\section{TABLES}

1. Schedule for guidance and ESH\&Q plans 



\section{ACRONYMS}

A\&PCT active and passive computed tomography

ANSI American National Standards Institute

ASME American Society of Mechanical Engineers

BWID Buried Waste Integrated Demonstration

CCU Contamination Control Unit

CFA Central Facilities Area

CTEN combined thermal/epithermal neutron

CTP Cold Test Pit

CTR Cooperative Telerobotic Retrieval

DC deployment coordinator

DDT differential-dieaway technique

DFC Digface Characterization

DOE U.S. Department of Energy

DQO data quality objective

DRCT digital radiography and computed tomography

EC Environment Checklist

EPA Environmental Protection Agency

ER/WM Environmental Restoration/Waste Management

ESH\&Q environmental, safety, health, and quality

FY fiscal year

GPR ground penetrating radar

GTCC greater-than-class-C

HEPA high efficiency particulate air 


\begin{tabular}{|c|c|}
\hline HPGe & high purity germanium \\
\hline IDC & integrated demonstration coordinator \\
\hline INEL & Idaho National Engineering Laboratory \\
\hline LITCO & Lockheed Idaho Technologies Company \\
\hline LLW & low-level radioactive waste \\
\hline MIT & Massachusetts Institute of Technology \\
\hline MPM\&P & Machine Performance Monitoring and Prediction \\
\hline NBRC & North Boulevard Robotics Complex \\
\hline NEPA & National Environmental Policy Act \\
\hline NQA & Nuclear Quality Assurance \\
\hline NTP & nonthermal plasma \\
\hline OTD & Office of Technology Development \\
\hline P/CAM & project/cost account manager \\
\hline PGNAA & Prompt Gamma Neutron Activation Analysis \\
\hline PgM & program manager \\
\hline PI & principal investigator \\
\hline PjM & project manager \\
\hline PM & project manager \\
\hline PNL & Pacific Northwest Laboratory \\
\hline PPE & Personal Protective Equipment \\
\hline QA & quality assurance \\
\hline QPP & Quality Program Plan \\
\hline R\&D & research and development \\
\hline REME & Remote Excavator \\
\hline
\end{tabular}




$\begin{array}{ll}\text { RHMMS } & \text { Radiological and Hazardous Material Measurement System } \\ \text { RWMC } & \text { Radioactive Waste Management Complex } \\ \text { SWPPP } & \text { Storm Waste Pollution Prevention Plan } \\ \text { TARG } & \text { Technical Academic Review Group } \\ \text { TMG } & \text { tensor magnetic gradiometer } \\ \text { TMGS } & \text { Tensor Magnetic Gradiometer System } \\ \text { TP\&SR } & \text { Technology Preparedness and Status Report } \\ \text { TRU } & \text { transuranic } \\ \text { TSG } & \text { Technical Support Group } \\ \text { TTP } & \text { Technical Task Plan } \\ \text { TTV } & \text { telerobotic transport vehicle } \\ \text { VETEM } & \text { Very Early Time Electromagnetics } \\ \text { VOC } & \text { volatile organic compound }\end{array}$




\section{Buried Waste Integrated Demonstration FY-95 Deployment Plan}

\section{INTRODUCTION}

The U.S. Department of Energy (DOE) Office of Technology Development (OTD) Buried Waste Integrated Demonstration (BWID) program is supporting the development, demonstration, testing, and evaluation of a suite of technologies that, when integrated with commercially available baseline technologies, form a comprehensive system for the effective and efficient remediation of buried waste throughout the DOE complex.

The FY-95 effort will deploy 11 major Idaho National Engineering Laboratory (INEL) field demonstrations, four INEL laboratory demonstrations, and six projects at non-INEL facilities. The three remaining technologies fall into the categories of office research (paper studies and computer simulations) and technical review meetings.

\subsection{Purpose and Scope}

This document defines the requirements for the technologies to be demonstrated in the field in FY-95. Technologies to be demonstrated in FY-96 or beyond are not considered in this document. The basic requirements to support the demonstrations of other technologies are also presented, but more briefly. Requirements such as safety and environmental protection are currently defined by facility managers and organizations responsible for the facilities in which the work will be performed. However, BWID is responsible for defining requirements for the INEL Cold Test Pit (CTP) and the North Boulevard Robotics Complex (NBRC) that are consistent with the Lockheed Idaho Technologies Company Safety Manual.

Soon after approval of the Technical Task Plans (TTPs), the principal investigators (PIs) were required to submit a Technology Preparedness and Status Report (TP\&SR) and Preparedness Checklist and Action Plan for review by the BWID Deployment Team and others. The Deployment Team consists of BWID and functional support staff with expertise in the areas of facility and operational planning, environmental compliance, safety, health, and quality. The information in these documents and interviews conducted by the Deployment Team with the PIs provided the basis for preparing this document and planning deployment of the 24 technologies funded by BWID in FY-95.

\subsection{Historical Perspective}

Funded by the DOE OTD, the goal of the BWID program is to provide innovative technologies in a timely manner for the DOE Environmental Restoration/Waste Management (ER/WM) Program. These technologies are being developed and demonstrated to assist ER in remediating the various buried waste sites throughout the DOE complex.

The amount of buried waste located throughout the DOE complex is estimated to be approximately 2.1 million cubic meters. The majority of this waste is located at the Hanford Site, 
the Savannah River Site, the INEL, the Oak Ridge National Laboratory, and the Rocky Flats Plant. The waste at these sites is buried or stored in trenches, pits, buildings, storage pads, or other structures.

Approximately half of all DOE buried waste was disposed of before 1970 . At that time, disposal regulations permitted the commingling of various types of waste [i.e., transuranic (TRU), low-level radioactive waste (LLW), and hazardous]. As a result, much of the buried waste throughout the DOE complex is believed to be contaminated with both hazardous and radioactive materials. DOE buried waste typically includes TRU, LLW, hazardous waste per 40 CFR 261, greater-than-class-C (GTCC) waste per 10 CFR 61 55, mixed TRU waste, and mixed LLW. Interstitial soils are also believed to be contaminated as a result of these disposal practices, which significantly increases the volume of materials requiring remediation.

Typical buried waste includes construction and demolition materials (e.g., lumber, concrete blocks, and steel plates), laboratory equipment (e.g., hoods, desks, tubing, and glassware) process equipment [e.g., heat exchangers, valves, ion exchange resins, and high efficiency particulate air (HEPA) filters], maintenance equipment (e.g., hand tools, cranes, oils, and greases), and decontamination materials (e.g., paper, rags, and plastic bags).

Various of disposal containers were used and included steel drums, cardboard cartons, and wooden boxes. Larger individual items were disposed of separately as loose trash. Degradation of the waste containers is believed to have resulted in contamination of the immediate surrounding soil.

\subsection{Interfaces}

The DOE OTD effort focuses resources through integrated programs and integrated demonstrations that are technology and problem specific. Integrated demonstrations and integrated programs have established the Program Planning Group, Technical Support Groups (TSGs), and a Technical Academic Review Group (TARG) to improve strategic planning efforts and technical integrity.

The BWID Program Planning Group has been structured to include representatives from the environmental restoration programs at DOE sites with significant amounts of buried waste; the Environmental Protection Agency (EPA), Region 10; and the State of Idaho.

TSGs consist of the anticipated end-users of a technology, such as ER/WM. Members of the TARGs include university and industry experts in the technology. Their purpose is to provide independent peer review of each project.

Systematic communication between BWID and the INEL Buried Waste Program, along with implementation of a systems analysis process, ensures that technology gaps are identified, appropriate technology demonstrations are funded, and technology transfer is facilitated.

Formal and informal communication has been established between the BWID project office and the PIs. Formal communications include weekly and monthly reports as well as quarterly technical review meetings. 


\subsection{Technology Descriptions}

The BWID project team structure showing all BWID funded technologies for FY-95 is shown in Figure 1. BWID nonfunded technologies are also shown. These technologies may be pursued as funding becomes available during FY-95.

The 24 technologies funded by BWID in FY-95 are described below. These technologies are divided into the two main types of demonstrations that will take place in FY-95: the INEL integrated field demonstration and research and development $(R \& D)$ demonstrations. The integrated field demonstration is divided into three categories by technology type: site characterization, hot spot retrieval/containment, and treatment/assay. The R\&D demonstrations are divided into five categories by technology type: waste characterization, site characterization, treatment/process control, containment/stabilization, and retrieval; and then subdivided by location of the demonstration or primary FY-95 effort.

\subsubsection{INEL Integrated Field Demonstration}

1.4.1.1 Site Characterization Technologies. Site characterization technologies that will be used in the integrated field demonstration are listed in the following subsections:

1.4.1.1.1 Imaging Infrared Interferometer-This technology, initiated in FY-94, will develop and test an infrared imaging system capable of real-time wide area volatile organic compound (VOC) monitoring of a waste remediation site. This will allow the remediation personnel to identify source, distribution, and nature of VOC emissions from digfaces, disposal areas, material conveyance systems, and processing equipmerit.

Physical Sciences, Inc., (PSI) has successfully demonstrated the operation of an innovative imaging interferometer with direct application to field detection of VOCs. The distinguishing feature between PSI's device and the proposed system is that the interferometer is operated with mirror spacings that are comparable to the desired transmission wavelength, such that continuous images of the field of view are produced with high sensitivity.

In FY-94, a subcontract with PSI was accomplished, allowing the design of an imaging infrared interferometer capable of meeting DOE waste-site characterization needs. Applications with EM-30 and 40 were identified and VOC database information obtained for Pit 9 and the INEL's Subsurface Disposal Area. Operating scenarios were formulated based on the BWID's integrated field demonstration for FY-94. Construction of the interferometer was initiated in FY-94 and was scheduled for delivery to the INEL February 1, 1995. The system will be installed and used in the integrated field demonstration. Glenn A. Moore of the INEL is the PI with much of the project being performed by PSI.

\subsection{Nonintrusive Sensing of Environmentally Important Objects and}

Species-The object of this task is to develop and improve a system for nonintrusive site characterization and object location at DOE sites through the measurement and interpretation of the Tensor Magnetic Gradiometer System (TMGS). This technology is applicable at DOE sites where magnetic targets are located. The term tensor magnetic gradiometer (TMG) is applied to 


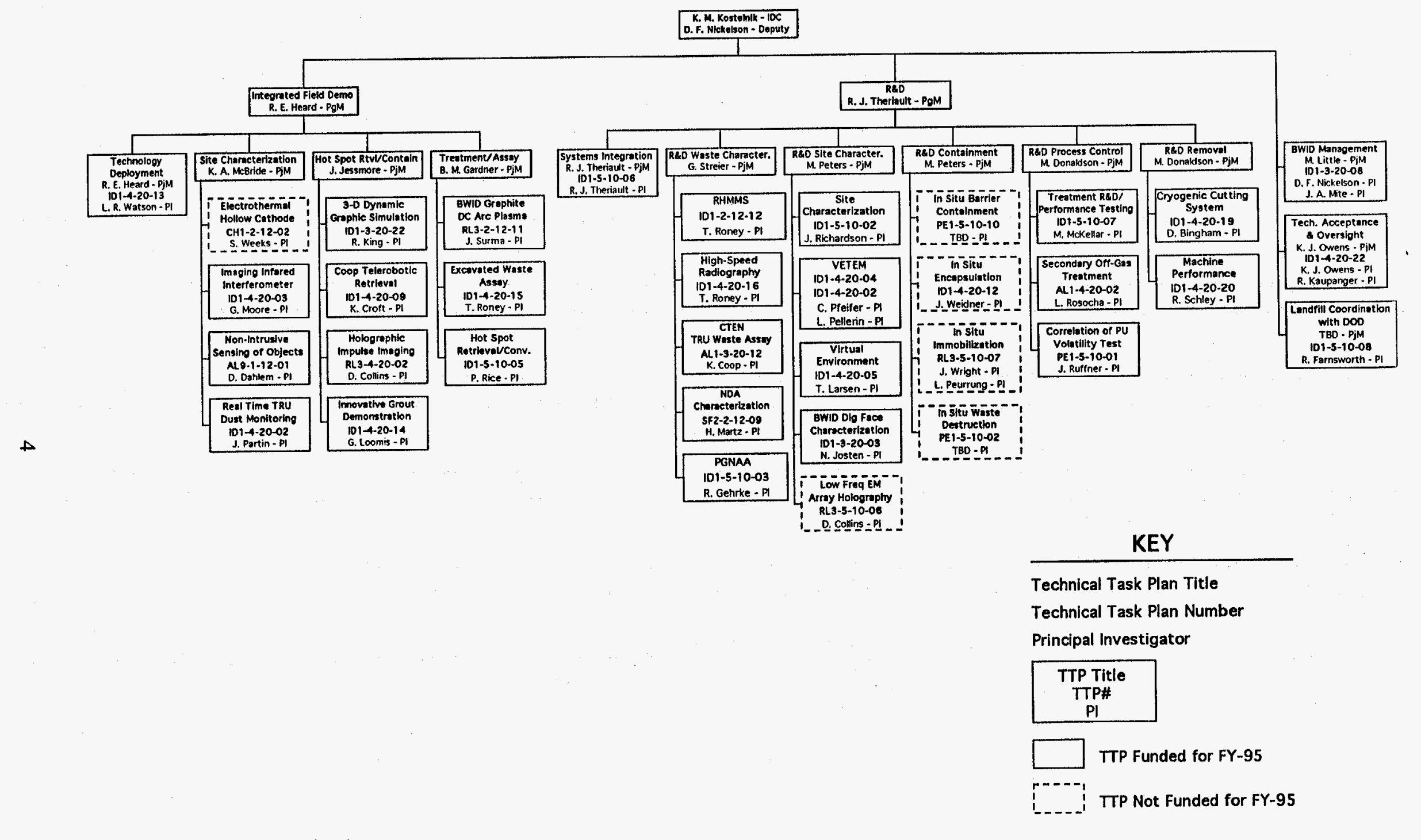

Figure 1. BWID organizational structure. 
an array of magnetometers or magnetic gradiometers whose output is used to assemble the gradient matrix or tensor.

A measurement of the gradient tensor at a single point preserves the directional information of the magnetic field and, thus, represents a very significant increase in the information about the anomalous magnetic field relative to the magnetic measurements typically acquired during site characterization. TMGs are not available commercially.

In FY-92, a full TMG was simulated by measuring the outputs from a single-beam gradiometer oriented in different orthogonal directions. During FY-93, a TMGS was assembled and supporting software developed. In FY-94, the TMGS was deployed first to Tucson, Arizona, and later at the CTP at the INEL's Radioactive Waste Management Complex. Tests in and around Tucson were conducted primarily for the purpose of assessing the calibration and performance of the TMGS system.

During FY-95 a more mobile platform will be fabricated for the TMGS and interpretive software for more complex model situations will be developed. The TMGS will take part in the INEL integrated field demonstration, as well as conduct additional demonstrations at other test sites. The PI is Carl G. Schwenk of RUST Geotech, Inc.

\subsection{Real-Time Monitoring of Transuranic Contaminated Dust-This} technology will develop and demonstrate a prototype instrument for true, real-time monitoring of TRU-contaminated dust. TRU waste-handling operations at DOE sites are expected to generate contaminated dust. Remediation-generated dust must be constantly monitored to protect personnel involved in remediation operations and to provide data to assess and control the spread of contamination. Current techniques involve time-weighted averaging using continuous air monitors and are not considered real-time.

During FY-94, a laboratory prototype was designed, procured, and fabricated. Bench-scale testing of the device was performed. FY-95 goals are to perform more detailed laboratory testing of the device to establish the optimum operational parameters. Testing of the device with plutonium will be continued. The design, fabrication, and testing of optical delivery and sampling systems for field installation will be performed. A field demonstration of the technology will be performed as part of the INEL integrated field demonstration. The PI is Judy K. Partin of the INEL.

1.4.1.2 Hot Spot Retrieval and Containment. Hot spot retrieval and containment technologies that will be used in the integrated field demonstration are listed in the following subsections:

\subsection{3-D Dynamic Graphic Simulation of Retrieval Configuration}

Options-This technology will focus on developing a comprehensive remediation system for ER/WM programs through modification of existing software packages to form three-dimensional images of retrieval sites that can then be used to carefully plan retrieval efforts in various waste scenarios. 
Work in FY-94 resulted in the ability of the performer to develop basic site presentations with equipment profiles superimposed. Equipment profiles are developed from schematic drawing information from the associated manufacturers.

FY-95 efforts will be to enhance the graphical capabilities of these displays, produce a library of equipment profiles, and enhance the display with the ability to simulate material (soil) removal. As part of the integrated field demonstration, this technology will be used to develop integrated waste removal scenarios with the various pieces of equipment and technologies that will be available. This will allow a retrieval plan to be developed and visualized prior to beginning removal operations. The PI is Robert King of the Colorado School of Mines.

1.4.1.2.2 Cooperative Telerobotic Retrieval-The Cooperative Telerobotic Retrieval (CTR) system consists of a gantry crane, two trolley mounted telescoping Z-mast assemblies, one trolley mounted 5-ton hoist, and two servo hydraulic manipulator systems fitted with end effectors designed to break up hard soil and carefully clean around buried objects. In addition, the CTR has been retrofitted with a remotely operated vacuum system that is designed to remove soil and debris.

The cooperative movement using the two manipulators is new in scope and has not been tested in the past. The CTR also provides for the remote delivery of a cadre of tools that will provide for remote material identification and removal from waste sites.

In FY-95 the CTR will be used in the integrated field demonstration where its primary focus of effort will be in the area of selective retrieval (hot spot retrieval). In addition to excavation and removal of waste, the CTR will be used to deploy various support systems (dust/ contamination control systems, soil vacuuming and sundering system, site characterization Holographic Impulse Radar Array, digface characterization sensors, and video monitoring equipment). The PI is Kevin M. Croft of the INEL.

\subsection{High Resolution Imaging of Buried Waste Using Holographic Impulse}

Radar Array-This research was initiated in FY-94 to develop, test, and demonstrate a field prototype ground penetrating holographic radar system for site characterization application in low conductivity soils.

The radar system employs a tapered slot antenna bistatic array system, which is suitable for analyzing at all depths of low conductivity soils, to scan subsurface target data and provide a three-dimensional holographic image. In FY-94, the arrays and imaging software were fabricated and developed by Pacific Northwest Laboratory.

In FY-95, preliminary field testing of the system will take place at the Underground Imaging Test Site located at Pacific Northwest Laboratory facilities next to the DOE Hanford Site in Washington. The results will be evaluated to determine the system's performance. Development of a $2.5-\mathrm{GHz}$ array and a crane-mounting fixture will be completed. A cart-mounted, 5- $\mathrm{GHz}$ system will be demonstrated at the INEL CTP. The $2.5-\mathrm{GHz}$ antenna array and mounting fixture will be used in the integrated field demonstration in assisting with retrieval operations. The PI is H. Dale Collins of Pacific Northwest Laboratory. 
1.4.1.2.4 Innovative Grout Demonstration-This technology involves two distinct tasks: provide a four-sided grouted wall surrounding a simulated waste pit and provide remote deployment of contamination control in the form of a misting, system and fixant/dust suppression system during the integrated field demonstration.

The innovative grouting concept employs a three-step field demonstration process: (1) the waste is jet grouted using up to 8,000 psi pressure into the soil waste/matrix, causing an agglomeration of fine soil particles that may be contaminated; (2) the cured monolithic block is fractured using a demolition grout; and (3) the debris is excavated in a relatively dust-free environment using a bridge crane. This technology was successfully demonstrated in FY-94 at the CTP. In FY-95, a four-sided wall was to be jet grouted around the integrated field demonstration's simulated waste pit to provide side stabilization for the hot spot retrieval activity. Because of funding cutbacks, this task has been eliminated. The concept may be demonstrated later this year at the CTP if funding becomes available.

The second task will involve the remote deployment of the Contamination Control Unit misting and fixant/dust suppression systems by the telerobotic retrieval manipulator arms of the gantry crane that will be used during the integrated field demonstration. The PI is Guy G. Loomis of the INEL.

1.4.1.3 Waste Assay and Treatment. Waste assay and treatment technologies that will be used in the integrated field demonstration are listed in the following subsections:

1.4.1.3.1 BWID Graphite DC ArC Plasma-This task involves the continued development of the graphite electrode DC arc technology for the treatment of buried waste. A national laboratory/university/private industry partnership has been established between Pacific Northwest Laboratory, Massachusetts Institute of Technology (MIT), T\&R Associates, and Electro-Pyrolysis, Inc., to conduct this task.

To date, a pilot-scale furnace (Mark II) with an array of process diagnostics has been developed. The Mark II system is installed in the Plasma Fusion Center at MIT. This furnace system will continue to support the BWID mission in fully evaluating the DC arc technology for the treatment of buried waste. In this capacity the Mark II system will continue to be optimized through the use of the process diagnostics. In addition, an engineering-scale radioactive furnace system will be designed, fabricated, installed, and tested at Pacific Northwest Laboratory.

FY-95 testing of the Mark II furnace will include waste taken from the integrated field demonstration. Because the Mark II furnace is not full scale, shredding of the waste will be necessary. The PI is Jeffrey E. Surma of Pacific Northwest Laboratory.

1.4.1.3.2 Excavated Waste Assay-The Excavated Waste Assay system will be developed to monitor waste streams either entering or leaving storage, or treatment facilities. The assay will be used to confirm and quantify the presence of TRU waste, to increase predictability and estimates of this waste, and to ensure disposal requirements are met for clean stream output of treated waste. 
The assay is conducted using a three-subsystem setup employing: (1) a real-time radiography to determine an average attenuation coefficient, (2) a very-high sensitivity gross-count scanner to determine gamma activity, and (3) a high energy resolution gamma-ray spectroscopy system for the identification and quantification of gamma-ray emitting TRU sources.

This technology will be developed at a minimum to the point of being able to assay a waste stream 5 inches deep. This performance will be demonstrated as part of the FY-95 integrated field demonstration. The PI is Timothy J. Roney of the INEL.

1.4.1.3.3 Hot Spot Retrieval/Conveyance Demonstration-This task will continue the development of the innovative end effector for dust free dumping and the robotic waste conveyance system that were successfully demonstrated in FY-94. The innovative end effector and the conveyance system were developed in close coordination with one another to ensure a systems design approach that will maximize the effectiveness of the combined technologies. The innovative end effector is deployed using the Remote Excavator (REMEX) that has been developed by SPAR Aerospace Ltd. and TSI Research Ltd.

The specially designed end effector features an inverted thumb and an attachable/detachable integrated transfer module. The inverted thumb has proven to be extremely versatile, dexterous, and productive in handling a variety of expected waste forms. The integrated transfer module acts as a detachable loading, handling, and conveyance bucket when digging, handling, and conveying waste. It is a rectangular, welded steel structure and holds approximately 1.4 cubic yards of soil and waste.

The remote conveyance system was designed and provided by RAHCO International. It consists of a track-mounted telerobotic transport vehicle (TTV) and a remote operator control station. The TTV transports the loaded/unloaded transport containers and integrated transfer modules. The remote operator control station is use for controlling the TTV, remote excavator, and video/audio systems.

The REMEX consists of a conventional Hitachi EX200LC excavator that has been modified for remote operation. All excavator functions that could be performed from the cab of the excavator can be performed from the remote control station.

In FY-95, the system will take part in the integrated field demonstration. The demonstration will focus on the removal of a hot spot(s) using the REMEX and innovative end effector with auxiliary support from the cooperative telerobotic gantry crane. Retrieved waste will be transported from the dig area by the TTV. The PI is Phillip M. Rice of the INEL.

\subsubsection{Research and Development Technologies}

\subsubsection{Waste Characterization Technologies.}

1.4.2.1.1 INEL Demonstrations-One INEL R\&D demonstration of waste characterization technologies is listed in the following subsection: 
1.4.2.1.1.1 Prompt Gamma Neutron Activation Analysis for Solving Waste Assay Problems-The purpose of this project is to provide for the development, performance testing, and utilization of Prompt Gamma Neutron Activity Analysis (PGNAA) as an on-stream nonintrusive method for the assay of waste material. The benefits of such a method would be on-stream elemental analysis in near-real time that would result in a high-quality product. This method of analysis has safety advantages, can save time, and under some conditions may provide a more accurate analysis since PGNAA can analyze the bulk waste and is not contingent upon the quality of the sampling protocol.

PGNAA involves the excitation or the capture of interrogating neutrons by nuclei in the material being assayed. These nuclei promptly emit gamma rays characteristic of the affected nuclei. The gamma rays are detected with gamma-ray spectrometers with the spectral shape and peaks indicating the elements associated with the emitted garnma rays. Although PGNAA has been used over a number of years, broad application is still not a reality since noninvasive elemental assay is not commonly required by most industries.

FY-95 efforts will use the PGNNA techniques that have: been developed for other applications and apply them to the vitrification (melter) environment. This will include developing standards and working to perform quantitative and qualitative evaluation of materials in the vitrification process. The PI will work with several of the BWID-funded melter projects to determine restrictions and limitations for work within their technology, with emphasis on the melter at MIT. By mid-year a report will be developed to show the progress to date and to allow for decisions as to whether to continue this work effort. The PI is Robert J. Gehrke of the INEL.

1.4.2.1.2 Non-INEL Demonstrations-R\&D demonstrations of waste characterization technologies whose efforts will be performed in facilities other than the INEL are listed in the following subsections:

\subsection{High Speed Digital Radiography and Computer Tomography of}

Waste Drums-This technology will continue to investigate the potential capabilities and applications of a commercial $x$-ray scanner for the digital radiography and computed tomography (DRCT) of waste packages, with emphasis on drums. Improvements in the scanner leading to high throughput are being emphasized. Very dense drum characterization will also be investigated.

During FY-94, the DRCT scanner was upgraded by the original manufacturer, Scientific Measurements Systems, in its Austin, Texas, facility. The scanner was then moved to Idaho State University for installation and testing that will continue for approximately one year.

It is anticipated that by July or August 1995 the work on the scanner will be advanced to a point where the scanner can be moved to the Stored Waste Examination Pilot Plant at the INEL for continued testing on Waste Isolation Pilot Plant type drums. This assumes that the new facility that will support this effort will be completed. The PI. is Timothy J. Roney of the INEL.

1.4.2.1.2.2 Improved TRU Waste Assay-Initiated in FY-93, this technology will be used to develop an enhancement to the currently used differential-dieaway technique 
(DDT), which uses thermal neutrons to interrogate for fissile isotopes in waste drums. The combined thermal/epithermal neutron (CTEN) method will be similar to DDT, but will interrogate the sample with both thermal and epithermal neutrons to overcome self-shielding effects and subsequent misinterpreted assay results prevalent in the DDT method.

In support of assay requirements prior to interim storage or treatment, the CTEN method employs ${ }^{4} \mathrm{He}$ detectors to expedite response and detection of fast fission neutrons in the presence of the epithermal interrogating flux, along with a redesign of the moderating cavity to ensure thermalization occurs more slowly. Once developed, a CTEN system could perform all the functions of existent DDT/passive-action neutron devices with the added capability of identifying and assaying lumps of material.

During FY-94, the CTEN waste assay instrument was designed, individual components fabricated, and assembly of the instrument completed. Much of the software required to collect data from the many detectors in the CTEN instrument was also written.

The goal for FY-95 is to characterize the new CTEN instrument in terms of detection limits, achievable accuracy, and limitations, while simultaneously developing the algorithms needed to optimize the assay results obtainable with this instrument. In FY-96 the instrument will be delivered to the Stored Waste Examination Pilot Plant at the INEL for the BWID demonstration. The PIs are Kenneth Coop and Robert Estep of Los Alamos National Laboratory.

\subsection{Nondestructive Assay Characterization Using Active and} Passive Computed Tomography-This technology, initiated in FY-93, will evaluate a gamma-ray-based active and passive computed tomography (A\&PCT) system on LLW and TRU waste contained in 55-gal drums. Once this technology is developed, waste drums can be nondestructively and accurately categorized to satisfy repository and regulatory guidelines prior to subsurface burial.

During FY-95, this effort will complete the development of a prototype single-high purity germanium (HPGe) detector that uses the principles of computed tomography and gamma-ray spectral analysis to identify and quantify all detectable radioisotopes within closed waste containers. After several field demonstrations, tests, and evaluations are carried out (by end of FY-96), it will become clear what further developments are needed to make the A\&PCT technology practical. The PIs are Harry E. Martz, Jr., and Daniel J. Decman of Lawrence Livermore National Laboratory.

1.4.2.1.3 Office Research - One office research project that involves R\&D of waste characterization technologies is listed in the following subsection:

\subsection{Radiological and Hazardous Material Measurement System}

(RHMMS)-This effort will tie together several assay technologies that are being developed to nonintrusively determine the radiological contents of some 300,000 waste drums at the INEL. This project minimally provides integration of the various measurement subsystems (CTEN, $\mathrm{DRCT}$, and A\&PCT) to interactively and algorithmically develop an improved assessment of containerized waste, compared to individual measurements. 
FY-95 efforts shall continue the multiple measurement integration tasks and their applicability to a variety of characterization projects throughout the DOE complex. This project is divided into three main technical areas: (1) computer software development (including algorithm development), (2) efforts to tie the system together for the integrated field demonstration, and (3) photon interrogation development. The photon interrogation effort and much of the computer software development will not be work:ed until future funding is made available. This leaves work to evaluate algorithms and some software efforts along with coordinating efforts for the integrated field demonstration to be worked in FY-95. The work will continue to coordinate the efforts to bring these systems together at the INEL for an integrated demonstration in FY-97 or FY-98. The PI is Timothy J. Roney of the INEL.

\subsubsection{Site Characterization Technologies.}

1.4.2.2.1 INEL Demonstrations-INEL R\&D demonstrations of site characterization technologies are listed in the following subsections:

\subsection{BWID Digface Characterization-The Digface Characterization}

(DFC) system consists of three technologies: (1) a sensor subsystem, (2) a deployment subsystem, and (3) a data handling subsystem. These technologies combine to measure various types of data directly at the point of active excavation and analyze these data in a timely fashion in order to support immediate decision-making during waste retrieval.

A prototype system incorporating basic forms of each technology element was assembled in FY-93 to begin evaluating the DFC concept. Initial development of DFC has focused on obvious and readily achievable functions-mapping solid waste distributions, radiation fields, and volatile chemical plumes. Two years of field testing have led to important refinements in understanding the system's potential role in a hazardous site cleanup. The DFC technology has reached a level of development where it is very difficult to further demonstrate its usefulness outside of the "hot" environment.

Efforts for FY-95 are aimed at preparing for a hot demonstration of the DFC characterization technology. The required tasks include: (a) a hot site selection, (b) designing a system to accomplish the hot demonstration, and (c) preparing a data-handling system based on results form prior cold demonstrations. The DFC characterization technology will be deployed from a remotely operated gantry crane and take part in the integrated field demonstration to be conducted at the INEL's NBRC in June to August 1995. The PI is Nick E. Josten of the INEL.

\subsection{Virtual Environment: Applicaticns to Buried Waste-This}

technology was initiated in FY-94 to investigate the feasibility of developing a computer-generated virtual environment for buried waste sites. FY-95 efforts will be to determine the methods, algorithms, and tools that will best assist in the translation of site characterization information to the production of a virtual environment.

Generation of virtual environments can be an important tool for site characterization analysis, strategy, and design of actual remediation efforts and systems. Using a simulation-based planning design concept (which applies computer simulation tools into the engineering process) 
researchers will use site characterization data and perform physics modeling to develop a prototype virtual environment.

Current scope will develop a real-time stereo imaging system incorporating visual, integrated characterization, and historical information as an aid to remediation operations personnel in the FY-95 integrated field demonstration. The PIs are Thomas K. Larson and L. Eric Greenwade of the INEL.

1.4.2.2.2 Non-INEL Projects-One R\&D demonstration of site characterization technologies whose efforts will be performed in facilities other than the INEL is listed in the following subsection:

1.4.2.2.2.1 Very Early Time Electromagnetics (NETEM)-The object of this task, initiated in FY-94, is to develop a VETEM system that is optimized for the detection and characterization of buried waste and local subsurface geology in the upper 10 meters below the surface. An electromagnetic system operating at very early times is not only sensitive to structures in the shallow subsurface, but also gives information on the its dielectric permittivity, as well as electrical conductivity properties. Development of a system that gives information on both these physical properties would help optimize characterization of the geoelectric section where buried waste is often located.

There are three important elements that are necessary and interconnected for VETEM to be successfully developed and deployed: (1) forward modeling, (2) instrumentation design, and (3) interpretation schemes that are rapid for real-time imaging.

FY-95 efforts will be to complete numerical modeling forward algorithms, complete a prototype time-domain instrument, perform demonstration tests of prototype instruments, and develop and test interpretative software. The PIs are Louise Pellerin of the U.S. Geological Survey and M. Cathy Pfeifer of the INEL.

1.4.2.2.3 Office Research-One office research project that involves R\&D of site characterization technologies is listed in the following subsection:

\subsection{Site Characterization and Ground Penetrating Radar (GPR)}

Consortium-The purpose of this task is to support several BWID site characterization R\&D activities through the following:

1. Conduct a BWID Geophysics Workshop whose objectives are to allow presentation and peer review of ongoing BWID-funded geophysics activities, discuss emerging technologies that hold promise for buried waste characterization, establish a baseline for evaluation of nonintrusive characterization technologies, and create a set of data quality objectives for advanced buried waste site characterization technology development.

2. Support a ground penetrating radar (GPR) consortium. This activity consists of a group of experts in GPR technology whose purpose is to review and advise the BWID program on GPR technology applications. Also included in this activity are directed 
technical investigations to address specific programmatic problems of limited scope that provide direct benefit to the BWID site characterization activities. This subtask also includes a yearly GPR workshop, hosted by the program, to expedite peer communication and provide a forum for discussion of emerging technologies, possible commercial involvement, and ideas and recommendations for future technical activities.

The PI is John Richardson of the INEL.

\subsubsection{Containment/Stabilization Technologies.}

1.4.2.3.1 INEL Demonstrations-No INEL R\&D demonstrations of waste containment/stabilization technologies are funded in FY-95.

1.4.2.3.2 Non-INEL Projects-No non-INEL R\&D demonstrations of waste containment/stabilization technologies are funded in FY-95.

1.4.2.3.3 Office Research-No office research that involves R\&D of site characterization technologies is funded in FY-95.

\subsubsection{Treatment/Process Control Technologies.}

1.4.2.4.1 INEL Demonstrations-No INEL R\&D demonstrations of waste treatment/process control technologies are funded in FY-95.

1.4.2.4.2 Non-INEL Projects-R\&D demonstrations of waste treatment/process control technologies whose efforts will be performed in facilities other than the INEL are listed in the following subsections:

\subsection{Secondary Treatment of BWIL) Off-Gas Using Nonthermal}

Plasma-This technology, initiated in FY-94, will continue to investigate the capability of nonthermal plasma (NTP) to promote favorable chemistry for the destruction of VOCs and metal oxidation through nonincineration means.

The NTP process employs electrical energy in the process chemistry to precise highly reactive free radicals that oxidize or reduce pollutants, fragment pollutants, or promote excited-state chemistry. A high voltage is applied between the electrodes; thus creating a micro discharge on gases flowing between them. This energy is then channeled into free radical production. This technology can also be used for treatment of secondary waste gases from commonly used treatment process for mixed waste, including vitrification, incineration, and thermal stripping.

FY-95 efforts will be to adapt existing technology to the treatment of melter off-gases and to perform a pilot demonstration for BWID. Efforts will also integrate construction and testing of NTP units with those for an expedited demonstration by the Committee to Develop Onsite Innovative Technologies (DOIT). The PI is Louis Rosocha of the Los Alamos National Laboratory. 


\subsection{Correlation of Metal Volatility Test to BWID and INEL Pit 9}

Tests-The objective of this task is to capitalize on INEL Pit 9 plutonium volatility tests using a small-scale plasma furnace completed during the fall of 1993 and correlate the results from the "hot" testing to the cesium tests completed under the BWID Program and Pit 9 Proof of Principle Duration Tests with the Plasma Centrifugal Furnace at the DOE by the PI prior to BWID approval. The PI is Jeff Ruffner.

1.4.2.4.3 Office Research-One office research that involves R\&D of waste treatment/process control technologies is listed in the following subsection:

1.4.2.4.3.1 Treatment R\&D/Performance Testing-The purpose of this project is to demonstrate the applicability of commercially existing arc melter technology to the treatment of mixed transuranically contaminated waste and soils (buried or stored) at the INEL and other DOE sites. Testing will be performed in the existing three-phase arc melter furnace system test facility at the U.S. Bureau of Mines Albany Research Center.

With the funding hold back for FY-95, this TTP is limited to supporting the preparation of the quick-look data report and the final test results report for the Bureau of Mines Phase II AC plasma arc melter system in Albany, Oregon. The quick-look report will cover the initial results from the AC arc melter test scheduled to be performed in late December 1994 and early January 1995. The final test results report will build on the quick-look report and include follow-on data evaluation, including results from all analytical lab analysis on all process material samples (slag, metal, fume, etc.). The PI is Michael G. McKellar of the INEL.

\subsubsection{Retrieval Technologies.}

1.4.2.5.1 INEL Demonstrations-INEL R\&D demonstrations of waste retrieval technologies are listed in the following subsections

1.4.2.5.1.1 Cryogenic Cutting System-The purpose of this effort is to demonstrate a remotely deployed system that can size reduce waste objects using atmospheric cryogenic fluids in a cutting process. Advantages over current sizing and cutting technologies include no generation of a secondary waste stream, elimination of flame coincidental with plasma arc cutting tools, and no size or strength limitations coincidental with shears.

Cryogenic cutting is a technique similar to abrasive waterjet cutting except the water is replaced by a liquefied atmospheric gas (i.e., nitrogen) and the abrasive solid is replaced by a solidified atmospheric gas (i.e., carbon dioxide crystals). These gases rapidly return to their natural state after being expended in the cutting process. The fluid jet is generated by exhausting nitrogen at $60,000 \mathrm{psi}$ at $-228^{\circ} \mathrm{F}$ through an orifice between 0.13 and 0.39 millimeters in diameter. A special nozzle is used to mix the solid gas particles with the high velocity jet.

FY-94 efforts were aimed at enhancing the cryogenic jet cutting technology. The system underwent modifications that produced a $375 \%$ to $648 \%$ improvement over the unmodified system. Variation in the improvement was dependent on the material being cut. 
FY-95 efforts will focus on four areas: (1) acquiring the appropriate enhancements to existing manipulation components for positioning of the jet, (2) enhancing the production capacity and instrumentation of the system to achieve control throughout the full operating range of the system, (3) obtaining jet input/output relationships for use in control laws to be executed by automated processes, and (4) demonstrating the control of the jetting and manipulation process. The PI is Dennis N. Bingham of the INEL.

\subsection{Machine Performance Monitoring and Prediction-This} technology, initiated in FY-93, involves developing a monitoring and prediction system for hydraulic, mechanical, and electrical failures of remotely operated equipment. The Machine Performance Monitoring and Prediction (MPM\&P) system will provide information on the current and future status of remotely operated equipment to the operator. MPM\&P will result in a reduction of remotely operated machine breakdown, hazarclous exposure to personnel in analyzing and repairing equipment, and lower operating costs. The information provided by MPM\&P will enable the operator to make informed decisions on the operation and maintenance of the equipment.

FY-94 efforts included the construction and operation of three test benches in order to collect the large quantity of failure mode data required to enable estimation of failures. Five pumps were run to failure in addition to several cavitation experiments. All of the data have been recorded and stored.

During FY-95, the MPM\&P system will be implemented on the remotely operated Caterpillar 325L excavator located at Tyndall Air Force Base. The system will be used during all operations performed by Wright Laboratories to allow sufficient data to be collected for interpretation. The data acquired during system operations will be interpreted for failure trend analysis and system verification. Other tasks to be accomplished in FY-95 are as follows: development and implementation of algorithms for failure prediction, testing of the code on the test benches, continued operation of the test benches and collection of data, and data comparison and validation. The PI is Robert S. Schley of the INEL.

1.4.2.5.2 Non-INEL Projects-No non-INEL R\&D demonstrations of waste retrieval technologies are funded in FY-95.

1.4.2.5.3 Office Research-No office research that involves R\&D of waste retrieval technologies is funded in FY-95. 


\section{ORGANIZATION AND RESPONSIBILITIES}

\subsection{Organization Chart}

The BWID organizational structure is depicted in Figure 1. Figure 2 shows a chart of the BWID Deployment Team.

\subsection{Personnel Responsibilities}

\subsubsection{Project/Cost Account Manager}

The project/cost account manager (P/CAM) is responsible for ensuring project compliance with DOE and management and operation contractor requirements, DOE orders, and BWID directives. The P/CAM must develop and maintain the baseline for the project; ensure that the project meets cost, schedule, and scope objectives; and ensure all sponsored work maintains technical integrity. The P/CAM is responsible for providing weekly and monthly reports to BWID on the project.

\subsubsection{Integrated Demonstration Coordinator}

The integrated demonstration coordinator (IDC) functions as the focal point for all contacts and correspondence relative to BWID. The IDC is responsible for ensuring that the BWID programmatic objectives are achieved by recommending technologies and projects to the DOE OTD through the DOE Idaho Operations Office for inclusion in BWID and to support other integrated demonstration and integrated programs. The IDC oversees technology evaluations and programmatic direction with the assistance of the TSGs and TARGs. The IDC also functions as the principal interface with other OTD-sponsored integrated demonstrations or integrated programs.

\subsubsection{Deployment Coordinator}

The deployment coordinator (DC) is responsible for sound project management practices and coordinating required activities for BWID-sponsored TTPs. The IDC is responsible for monitoring technical progress, cost, and schedule performance of all participating organizations in accordance with established TTPs. The DC reports to the IDC on programmatic progress, makes recommendations affecting budgets and schedules, and suggests corrective actions as appropriate. The DC is responsible for assessment of project risk and contingency planning that identifies critical systems, subsystems, and other areas requiring focused analysis and resolution. Risks appear in technical, schedule and cost, quality, environmental, health, safety, regulatory, and utility areas. It is the responsibility of the $\mathrm{DC}$ to ensure that authority is clearly delegated and accountability for performance is established.

The deployment project manager (PM) directly supports the $\mathrm{DC}$ to ensure that all tests are conducted in accordance with approved test plans and in compliance with all applicable regulations. The deployment $\mathrm{PM}$ is the focal point for all participating organizations who 


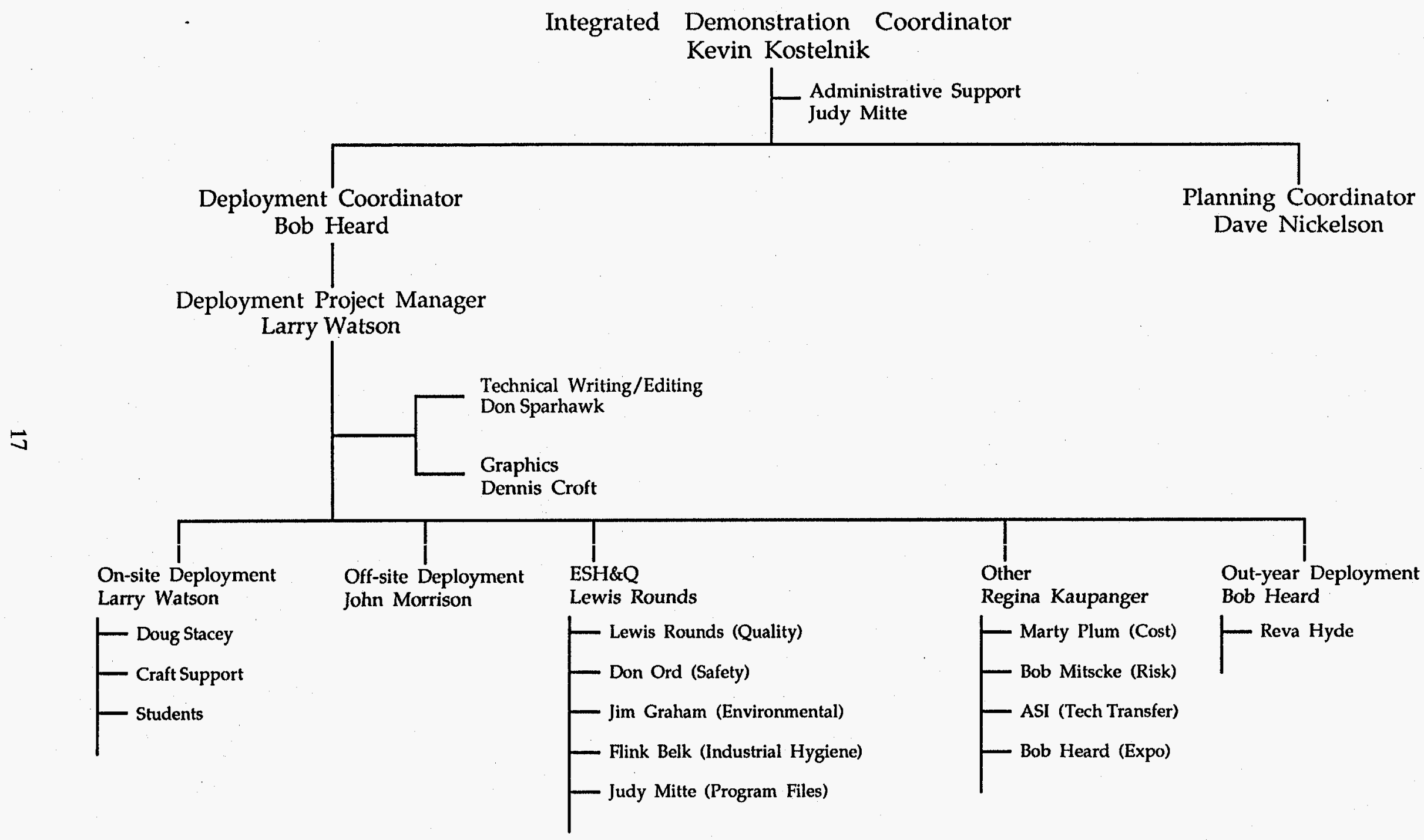

Figure 2. BWID Deployment Team. 
demonstrate technologies under BWID. In FY-95, the DC is Bob Heard and the deployment PM is Larry Watson.

\subsubsection{Site Monitor}

During field testing, a designated BWID representative (site monitor) shall be present while equipment is operating. The site monitor has the responsibility to monitor and, if necessary, shut down operations. The site monitor shall observe all operations to ensure that the operations do not endanger the safety of any worker or the environment. The site monitor shall also receive copies of all data and logbooks and is responsible for ensuring that these data are properly transmitted to the BWID office database manager to be scanned into the system. Site monitors support the deployment PM. During FY-95, site monitors for INEL tests will include Larry Watson and Doug Stacey. The site monitor for INEL laboratory demonstrations will be Larry Watson or a qualified delegate. For offsite tests, John Morrison is the site monitor. 


\section{ESH\&Q BWID DEPLOYMENT SUPPORT}

\subsection{Description of BWID ESH\&Q Deployment Support}

BWID has recognized that environmental, safety, health, and quality (ESH\&Q) support will be required for successful demonstration and testing of technologies. This section provides information describing the support requirements to ensure proper ESH\&Q oversight defined by the technology PIs and the BWID Deployment Team.

Each TTP, TP\&SR, Technology Preparedness Checklist and Action Plan, and Test Plan has been or will be reviewed by BWID personnel to identify operational support needs and issues. Resolution was and will be achieved through correspondence and discussions with the PIs. All issues raised as a result of the checklist review must be resolved, and the resolution approved by the BWID project manager before the demonstration can begin field operations. An approval to begin operations letter will be sent to the PI by the BWID deployment PM.

Operational support needs, such as communications equipment, portable generators, etc., have been identified and will be provided as required (some subcontractors may prefer to provide their own equipment) by BWID. Operational support requirements are discussed in Section 4.

\subsection{Environmental Documentation}

The following sections discuss environmental compliance documents that are required for BWID projects. Areas addressed include National Environmental Policy Act (NEPA) documentation, a Storm Waste Pollution Prevention Plan (SWPPP) for the CTP, archaeological surveys, and threatened and endangered species surveys.

\subsubsection{National Environmental Policy Act Documentation}

Each TTP supported by BWID must have approved N]EPA documentation prior to starting activities. BWID has obtained NEPA approval for construction of the CTP. The PIs are responsible for completing Environmental Checklists for their individual projects. BWID will ensure that proper NEPA approvals and conditions specified have been met before commencing with covered activities. Copies of all NEPA documentation will be kept in the BWID program files.

\subsubsection{Storm Water Pollution Prevention Plans}

A SWPPP is required for construction activities at the INEL. A SWPPP has been prepared and approved for activities at the CTP.

\subsubsection{Archaeological Surveys}

Archaeological surveys are required of U.S. Government agencies before performing any activity that disturbs the ground in previously undisturbed areas. The survey checks the area for any archaeologically significant articles and needs to be performed only once for an area. An 
archaeological survey has been performed for the CTP and is documented in the BWID project files.

\subsubsection{Threatened and Endangered Species Surveys}

A threatened and endangered species survey has been performed for the construction of the CTP. This survey is documented in the BWID project files.

\subsection{Hazard Classifications}

Hazard classification determinations are required on all projects. The BWID Deployment Team supports projects in obtaining hazard classification determinations for each project by documenting the projects and obtaining Independent Safety Review Committee evaluations on those projects that require this level of review. Activities of the BWID Deployment Team do not require hazard classifications separate from the demonstration projects.

\subsection{Technology Assessments}

Technology assessments are performed by the Deployment Team for all field and laboratory tests. Technology assessments entail reviewing the project's equipment and instrumentation readiness for testing. Technology Assessment Reports will be written within two weeks after the project review.

\subsection{Sampling and Data}

Sampling techniques and data collection procedures for each technology project are discussed in the individual test plans. However, the BWID Deployment Team will collect data on general events, deployment activities, and the environmental conditions at the CTP and the NBRC. This is discussed further in Section 3.6.3, "Logbooks."

\subsection{Document Control}

\subsubsection{Data Management}

Each of the technologies being tested has its own data management system; however, BWID has a database that all data, logbooks, and reports must be scanned into from all the technologies (field tests, laboratory tests, and paper studies). The BWID site monitor and the PI are responsible for ensuring that all raw data and laboratory notebooks used during laboratory and field tests (on and offsite) are copied and supplied to the database manager within one week of completing the tests. Raw data should be in its original form (electronic or hard copy) whenever possible. A hard copy of electronic data shall also be supplied but may be delivered up to one month after testing. The technology project manager is responsible for ensuring that all other documentation is given to the database manager. 


\subsubsection{Reports}

To ensure that the technologies, whether paper studies, laboratory tests, or field tests, provide useful data, the BWID Deployment Team has issued the following documents:

- Technology Preparedness and Status Report Guidance, EGG-WTD-10266, Rev. 1

- $\quad$ BWID Test Goals and Objectives, EGG-WTD-11112, Rev. 0

- Test Plan Guidance, EGG-WTD-9800, Rev. 1

- Technology Evaluation Report Guidance, EGG-WTD-10104, Rev. 2.

To ensure that the demonstration results are reported to interested parties, the following methods of data reporting will be used:

- Technology Evaluation Report-The data generated by the demonstration, as well as information on the planning and deployment of tests, will be assembled and documented in a Technology Evaluation Report. 'The Technology Evaluation Report will summarize the tests, test results, and lessons learned, and will provide recommendations for further development. This is the responsibility of the technology PIs.

- Publications-Information on the demonstrations and their results may be submitted by PIs for publication to the Waste Management ' 96 Conference and other waste management or environmental restoration related journals, conferences, and meetings. PIs shall inform BWID of such publications and presentations through the weekly reports to BWID.

- FY-95 Close-out Report-The BWID management team will produce an FY-94 Close-out Report that discusses the results of all of the projects. This report will be issued in FY-96.

\subsubsection{Logbooks}

BWID will maintain a daily logbook for INEL field tests as an overall program record. The following information will be recorded in this logbook:

- Environmental conditions, including temperature, approximate wind speed, precipitation

- Observations of technology integration problems and their resolutions

- Lessons learned

- Incidence and disposition of any injuries or accidents occurring at the CTP or the integrated field demonstration at the NBRC. 
A separate record will be maintained listing all personnel and visitors present at the CTP and the integrated field demonstration at the NBRC. A logbook of laboratory testing at the INEL will also be maintained by BWID with the same information, where applicable.

\subsection{Quality Assurance}

All BWID projects must have a documented quality program that addresses the basic elements identified in the American National Standards Institute/American Society of Mechanical Engineers (ANSI/ASME) Nuclear Quality Assurance (NQA) standard, NQA-1. For projects to be completed at the INEL, the quality program will follow the Lockheed Idaho Technologies Company (LITCO) Quality Assurance Manual and the Office of Waste Technology Development Quality Program Plan (QPP-044). Projects continuing on from previous years may use QPP-337 if it was originally designated. Both QPP-044 and QPP-337 include the requirements of NQA-1.

BWID projects demonstrated at other DOE facilities must comply with quality programs in effect at their locations. For projects being performed at other than a DOE facility, the quality program needs (NQA-1 basic requirements and supplements) must be addressed with the subcontract.

Data quality objectives (DQOs) shall be identified and addressed in a DQO document, test plan, or work release document as agreed to by the BWID project manager. BWID has provided test plan guidance to PIs in the Buried Waste Integrated Demonstration Program Technology Test Plan Guidance. Test plans will be reviewed for quality requirements by the BWID Deployment Team.

\subsubsection{Internal Quality Control Checks}

Internal quality control checks will be performed during and after testing. These include reviewing completeness and accuracy of the logbooks, executing performance and system audits, and checking to ensure that the established procedures are being followed.

\subsubsection{Performance and System Audits}

Performance audits are conducted to quantitatively and qualitatively evaluate the outputs of a measurement system. System audits are conducted to qualitatively evaluate the operational details of a quality assurance (QA) program. These audits will be conducted internally by the BWID Deployment QA support member.

A system audit to verify that the instrument(s) are operating within expected parameters will be done before and after the INEL demonstration by the respective operations personnel. This information will be documented in the PI's logbook. 


\subsection{Health and Safety}

\subsubsection{Safety Reviews and Checks}

The BWID safety engineer shall conduct a safety walk down of the CTP and the NBRC areas on a weekly basis when field demonstrations are being performed. The safety engineer (and any other involved person) has the authority to stop work if he considers it necessary. Safety discrepancies and concerns shall be reported to the BWID deployment PM. Corrections will be funded and completed by BWID or by the demonstration PI, depending upon the nature of the identified problem.

BWID and subcontractor personnel are responsible for complying with the applicable sections of the LITCO Safety Manual, LITCO Industrial Hygiene Manual, RWMC Operational Safety Requirements Safety Analysis Report, LITCO Conduct of Operations Manual, and Environmental Restoration Program Generic Health and Safety Plan. If required, safety-related training is available from centralized safety at the Central Facilities Area.

\subsubsection{Safe Work Permits}

All work performed at the INEL must be reviewed and approved by a facility health and safety representative and documented in safe work permits, as required. All work shall be performed in compliance with all of the health and safety requirements for the BWID project as identified in the BWID Project Management Plan.

\subsection{Residuals Management and Waste Minimization}

Procedures for disposal of solid waste are contained in the LITCO Company Procedures Manual, Section 8.12, "Solid Sanitary Waste Segregation and Recycling Procedures for Using the INEL Landfill." BWID will have three dumpsters placed at the CTP to receive metal, wood, and other refuse (e.g., office paper). Waste disposal is described further in Section 4.1.7.

Secondary waste from laboratory and field tests are the responsibility of the PI of each technology. The BWID Deployment Team will support the removal and ultimate disposal of secondary waste streams if requested by the PIs. In addition, if a secondary waste stream from one technology could be used as a resource on another project, the BWID Deployment Team will identify this and coordinate transfer of the waste/resource. For example, the integrated field demonstration will have retrieved simulated buried wasted as a secondary waste stream. The BWID Deployment Team has determined that this can be a resource for some of the treatment technologies. Therefore, instead of sending this simulated waste to the landfill, it will be boxed and sent to vendors participating in the treatment technology demonstrations or will remain at the CTP in boxes or with some other storage method. Disposal of secondary waste and other test residuals are the responsibility of the project PI. 


\section{DEPLOYMENT PLAN}

For the purpose of defining deployment needs, the BWID-sponsored technologies are divided into three sections: INEL demonstrations, non-INEL demonstrations, and paper studies.

\subsection{INEL Demonstrations}

The FY-95 effort will deploy 10 technologies in an integrated field demonstration at the North Boulevard Robotics Complex (NBRC). These technologies include: Imaging Infrared Interferometer, Nonintrusive Sensing of Environmentally Important Objects and Species, Real-Time Monitoring of Transuranic Contaminated Dust, 3-D Dynamic Graphic Simulation of Retrieval Configuration Options, Cooperative Telerobotic Retrieval, High Resolution Imaging of Buried Waste Using Holographic Impulse Radar Assay, Innovative Grout Demonstration, BWID Graphite DC Arc Plasma, Excavated Waste Assay, and Hot Spot Retrieval/Conveyance Demonstration. The objective of the demonstration will be the performance evaluation of multiple technologies integrated together to find, characterize, retrieve, assay, and treat waste that has been identified as a zone of environmental concern (hot spot). The technologies that will take part in the integrated field demonstration are shown in Figure 3.

BWID Graphite DC Arc Plasma will take part in the integrated demonstration, but will not be deployed at the INEL. Waste retrieved during the integrated demonstration will be shipped to the Plasma Fusion Center at MIT to be processed in the Mark II furnace.

Additional demonstrations to be performed at the INEL as research and development (R\&D) demonstrations include as follows: Prompt Gamma Neutron Activation Analysis (PGNAA) for Solving Waste Assay Problems, BWID Digface Characterization, Virtual Environment: Applications to Buried Waste, Cryogenic Cutting System, and Machine Performance Monitoring and Prediction. These five technologies will be performed at various INEL laboratories or at the CTP. The technologies are shown in Figure 4.

It is anticipated that additional technologies will be identified, funded, and demonstrated later in the year at the CTP.

\subsubsection{INEL Field Demonstrations}

All INEL field demonstrations will be performed either at the CTP or at the NBRC as part of the integrated field demonstration. While performing work at the NBRC, PIs must work within the landlord/tenant agreement and must comply with all access, security, safety, emergency plan, spill control plan, and other NBRC requirements. Additional requirements and BWID responsibilities for INEL field demonstrations are listed below.

\subsubsection{Facilities.}

4.1.1.1.1 Test Area Preparation-BWID responsibilities for pre demonstration site preparation at the CTP and the NBRC include the following activities: 


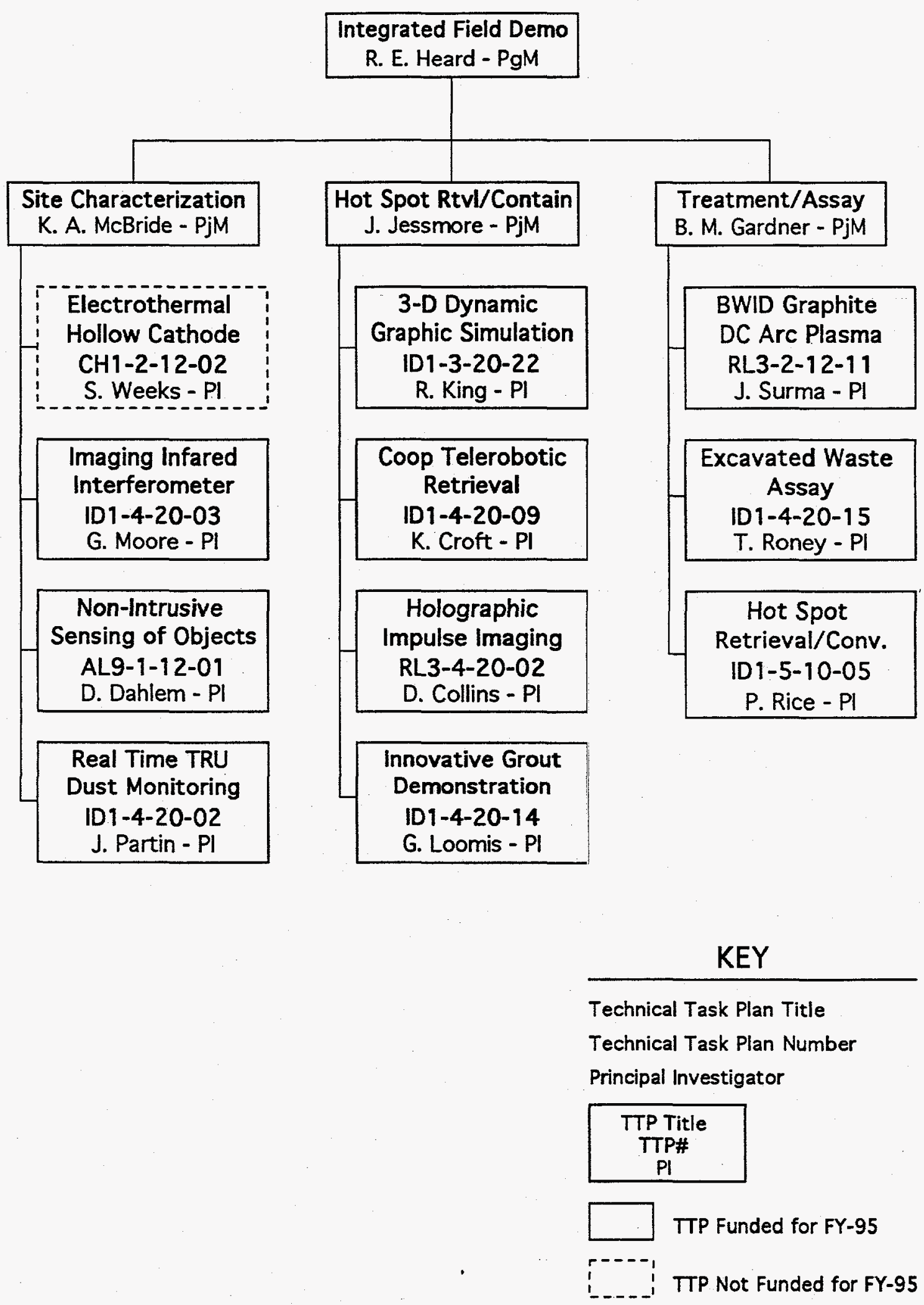

Figure 3. INEL integrated field demonstration technologies. 

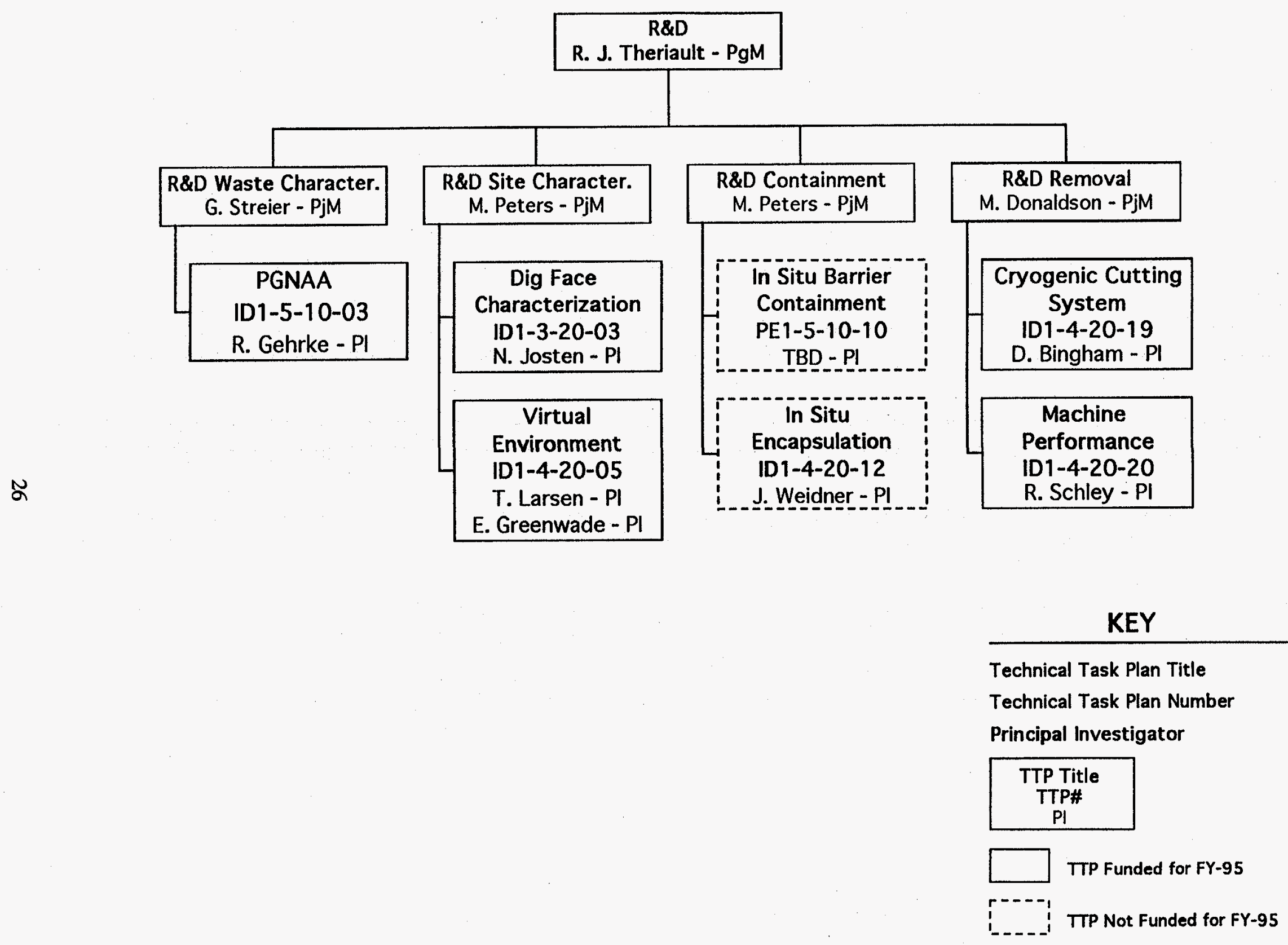

Figure 4. INEL R\&D demonstrations. 
- Coordinating the development of any new waste cells

- Filling and grading, as necessary, to prepare surfaces for trailer locations

- Installation of BWID signs for safety, security, and other important information

- Installation of sanitary facilities, trash containers, eyewash stations, drinking water, electrical generators, and communication systems

- Installation of the administrative support trailer and the remote operations trailer

- Arrangement for video/photographic services.

4.1.1.1.2 Interface Agreement with Radioactive Waste Management Complex (RWMC)-An interface will be prepared and approved by the BWID deployment PM and the RWMC building manager. This document will define roles and responsibilities for the BWID and RWMC at the CTP. The interface agreement should be reviewed by all PIs prior to demonstrating at the CTP.

4.1.1.1.3 Access and Security-Demonstrations performed at the NBRC will comply with existing NBRC access and security requirements. Access and security issues at the CTP will be discussed in the RWMC interface agreement. Adherence to all of the requirements is the responsibility of the PIs testing at the CTP.

BWID is responsible for arranging for security surveillance within the CTP area and the NBRC area. The RWMC shall modify the requirements of the roving watch to include a visual check of the CTP from inside the RWMC compound during normal rounds.

4.1.1.1.4 BWID Administrative Support Trailers-BWID will provide a $10 \times 24-\mathrm{ft}$ travel trailer to be used as an administrative support facility at the CTP. BWID will also provide a trailer at the NBRC to house the equipment and operators that will deploy technologies through remote operations during the integrated field demonstration. Each trailer will be equipped with a smoke detector and two fire extinguishers.

There will be no running water or liquid drains in the trailers. Bottled water for drinking will be supplied by BWID. Communications will be maintained with the RWMC and town facilities by radio and cellular phones.

4.1.1.1.5 Sanitary Facilities-BWID will supply portable toilets at the CTP and at the NBRC. There will be no running water or liquid drains. The toilets will be serviced once every week. Sanitary facilities are also available inside the gate of the RWMC and inside the NBRC.

4.1.1.1.6 Equipment, Instruments, and Supplies-BWID will supply and maintain the following supplies for field tests at the CTP and the NBRC:

- Safety equipment, including first aid kits, chemical dosimeters, fire extinguishers, and fire alarms. 
- All necessary signs for safety, traffic, information, etc.

- Waste receptacles for nonhazardous and nonradioactive waste.

- General hand tools.

- Personnel protective equipment, including hard hats, safety glasses, gloves, and eye wash stations.

- A weather station, supported by the National Oceanic and Atmospheric Association (NOAA) is located at the CTP. This station will provide the following information for any test requiring weather information: wind speed, wind direction, temperature, humidity, and barometric pressure.

The following services will be supplied for field tests at the CTP and the NBRC:

- Coordination of receipt of equipment at the test site.

- Site orientation and demonstration site training.

- The escort of visitors to site when necessary.

- Use of mobile phones.

- Fuel and water delivery. BWID will coordinate the delivery of fuel and water to the field demonstrations. Each project is responsible for the cost of their share of this service.

Equipment at both the CTP and the NBRC will be locked up at night and on days that they will not be required. The area behind the NBRC, where the integrated field demonstration will be held, is enclosed by an 8-foot high chain link fence. Protective measures will be taken to ensure that the equipment is not damaged during shipping to and from the INEL.

4.1.1.1.7 Crafts Support-BWID and BWID-funded demonstrations are responsible for budgeting, funding, and conducting maintenance and repair of all equipment, real property, and site restoration activities within the demonstration boundaries of both the CTP and the NBRC.

Since BWID is solely responsible for all crafts' activities within the demonstration area boundaries, the Radioactive Waste Management Complex Tenants Manual is not applicable to BWID activities conducted at the CTP. All work performed by RWMC personnel will be controlled, scheduled, and performed in accordance with existing, approved, and controlled procedures. In addition, if BWID contracts for RWMC capabilities, BWID will be bound by the Radioactive Waste Management Complex Tenants Manual and project directives as they apply to the contracted service. 


\subsubsection{Utilities.}

4.1.1.2.1 Electricity-Electrical power for the integrated field demonstration and trailer lighting will be provided by BWID. PIs must contact BWID as soon as possible to identify their electrical requirements.

4.1.1.2.2 Water-Well water is available and can be supplied to the CTP with a water truck from the RWMC or Central Facilities Area. Water is available for demonstrations at the NBRC. Water will be supplied by BWID operations support in case of fire and possibly for additional dust suppression. Drinking water will be available at the trailers and inside the NBRC.

\subsubsection{Transportation.}

The CTP is located adjacent to the RWMC approximately $\mathbf{5 2}$ miles from Idaho Falls. State Highway 20 passes between the RWMC and CFA. Bus service is available for INEL personnel Monday through Friday to CFA and Monday through Thursclay to the RWMC. The buses leave and return to CFA and Idaho Falls on regularly scheduled routes. Generally, INEL personnel will drive personal or INEL motor pool vehicles, and subcontractor personnel will drive personal or subcontractor vehicles to CTP.

The NBRC is located on the north side of Idaho Falls within the city limits. Generally, INEL personnel will drive personal or INEL motor pool vehicles, and subcontractor personnel will drive personal or subcontractor vehicles to the NBRC. All vehicles not directly participating in the integrated field demonstration will be required to park: outside of the chain-link fence that surrounds the demonstration site.

\subsubsection{Site Restoration.}

It is the responsibility of the PI of each demonstrated technology to remove all of their equipment and associated items from the test areas and restore the site to pretest conditions. BWID may request that the CTP or NBRC test site be returned to other than the pretest conditions and will negotiated the final pit condition prior to the technology entering the field.

4.1.1.4.1 Revegetation-Revegetation of the CTP demonstration site may or may not be necessary. This determination will be made by the BWID project manager.

4.1.1.4.2 Resurfacing-BWID will be responsible for returning the test site at the NBRC to its predemonstration condition. This will include backfilling, leveling, compacting, and resurfacing the postdemonstration pit. Determination of satisfactory restoration will be made by the BWID project manager and the landlord of the NBRC facility.

4.1.1.4.3 Additive Substances-Substances that are added to, in, or on the soil at the CTP or the NBRC may or may not need to be removed. Technology demonstrations wanting to consider the long-term remedial or environmental effects of such additives may leave the additives in place at the CTP with the written consent of the BWID project manager. The determination for the NBRC test site will be made by the BWID project manager and the landlord of the facility. Written approval of the BWID project manager is mandatory before deployment of 
technologies requiring such additives. Descriptions, amounts, and the locations of additives shall be supplied to BWID by the PI and added to the BWID program file.

4.1.1.4.4 Excess or Discarded Materials and Equipment-All construction material, lumber, excess or discarded equipment and supplies, either used or unused, must be removed from either site at the conclusion of the demonstration. Material relevant to long-term monitoring may be left at the CTP with the written approval of the BWID project manager. Material left at the NBRC will need the written approval of the BWID project manager and the landlord of the NBRC facility. Other discarded material is addressed in Section 3.9, "Residuals Management and Waste Minimization." Some materials may require sizing to facilitate disposal and will be an additional cost to the demonstration project.

\subsubsection{Medical and Emergency Plans.}

4.1.1.5.1 Emergency Response Plan-The Emergency Response Plan for BWID activities at the CTP is addressed in the BWID/RWMC Interface Agreement.

4.1.1.5.2 Spill Plan-The RWMC Spill Prevention Control and Countermeasures (SPCC) Plan will be used at the CTP. The SPCC Plan can be found in the RWMC Emergency Plan/RCRA Contingency Plan.

4.1.1.5.3 Medical Plan. First aid kits are located within the BWID administrative support trailers and RWMC guard gate. First aid certified personnel are assigned to the RWMC. Medical personnel, services, and facilities are located 7 miles from the CTP at the CFA.

BWID will be responsible to see that first aid certified personnel are present during demonstrations at the NBRC. Medical personnel, services, and facilities are located 6 miles from the NBRC at the Idaho Falls Regional Medical Center.

\subsubsection{Training.}

4.1.1.6.1 Training Responsibilities and Requirements-BWID has established training requirements and training responsibilities for BWID and BWID subcontractor personnel. Minimum requirements, training quality, and general guidance are defined in Training Requirements and Responsibilities for the Buried Waste Integrated Demonstration at the Radioactive Waste Management Complex. This document provides specific training requirements for each field project. A thorough review of these documents should be undertaken by the PIs early in the demonstration planning process.

The BWID Deployment Team and the demonstration PI are responsible for scheduling and coordinating training well before it is needed to avoid unnecessary demonstration delays. Individual project funds will bear the costs of any required training for project and subcontractor personnel. BWID will bear the costs for required training of BWID personnel. Adequacy and appropriateness of the training will be confirmed by the trainer and BWID project manager.

4.1.1.6.2 Demonstration Specific Training-PIs are responsible for ensuring that all project personnel receive the training applicable to their specific demonstration. 
4.1.1.7 Waste Disposal. BWID will have three dumpsters placed at the CTP and the NBRC to receive metal, wood, and other refuse (e.g., office paper). Demonstration personnel are responsible for separation of their waste to facilitate recycling. Disposal of any hazardous or otherwise controlled waste is the responsibility of the PI and the PM. BWID will assist with disposal, if requested.

\subsubsection{INEL Laboratory Demonstrations}

4.1.2.1 Facilities. Four laboratory- or bench-scale tests will be conducted in INEL laboratories in FY-95. PIs must work within the landlord/tenant agreements for each INEL facility and must comply with all access, security, safety, emergency plan, spill control plan, and other requirements of those facilities.

The PIs are responsible for identifying and following all facility specific requirements. They are also responsible for training any personnel involved in the demonstration. This includes access orientation training, facility specific training, and demonstration specific training.

4.1.2.2 Crafts Support. PIs may require general laborers, heavy equipment operators, electricians, support personnel from the INEL crafts' organization during testing and/or the BWID equipment exposition. BWID will be the central contact for RWMC and CFA labor used for BWID demonstrations. PIs should contact the BWID deployment team as soon as possible to arrange for this support.

\subsection{Non-INEL R\&D Demonstrations}

There are six demonstrations whose primary efforts will be performed in FY-95 at locations other than the INEL. These technologies are shown in Figure 5.

\subsubsection{Facilities}

These demonstrations will take place at non-INEL locations, including subcontractor sites, universities, and other DOE facilities. In all cases, PIs must comply with the facility regulations, landlord/tenant interface agreements, and security safety regulations of the facility in which the work is performed. PIs must also ensure compliance with all applicable DOE orders. PIs should consult with BWID Deployment Team personnel to resolve any issues or concerns.

The subcontractor is responsible for communications, utilities, and other services required to perform the demonstration. BWID will provide other services required to perform the demonstration. BWID will provide managerial review of the work and technical guidance during all phases of the project and will witness the field demonstration. No materials or other services will be provided by BWID. The subcontractor is also responsible for emergency medical and fire response, safety oversight, and training. 


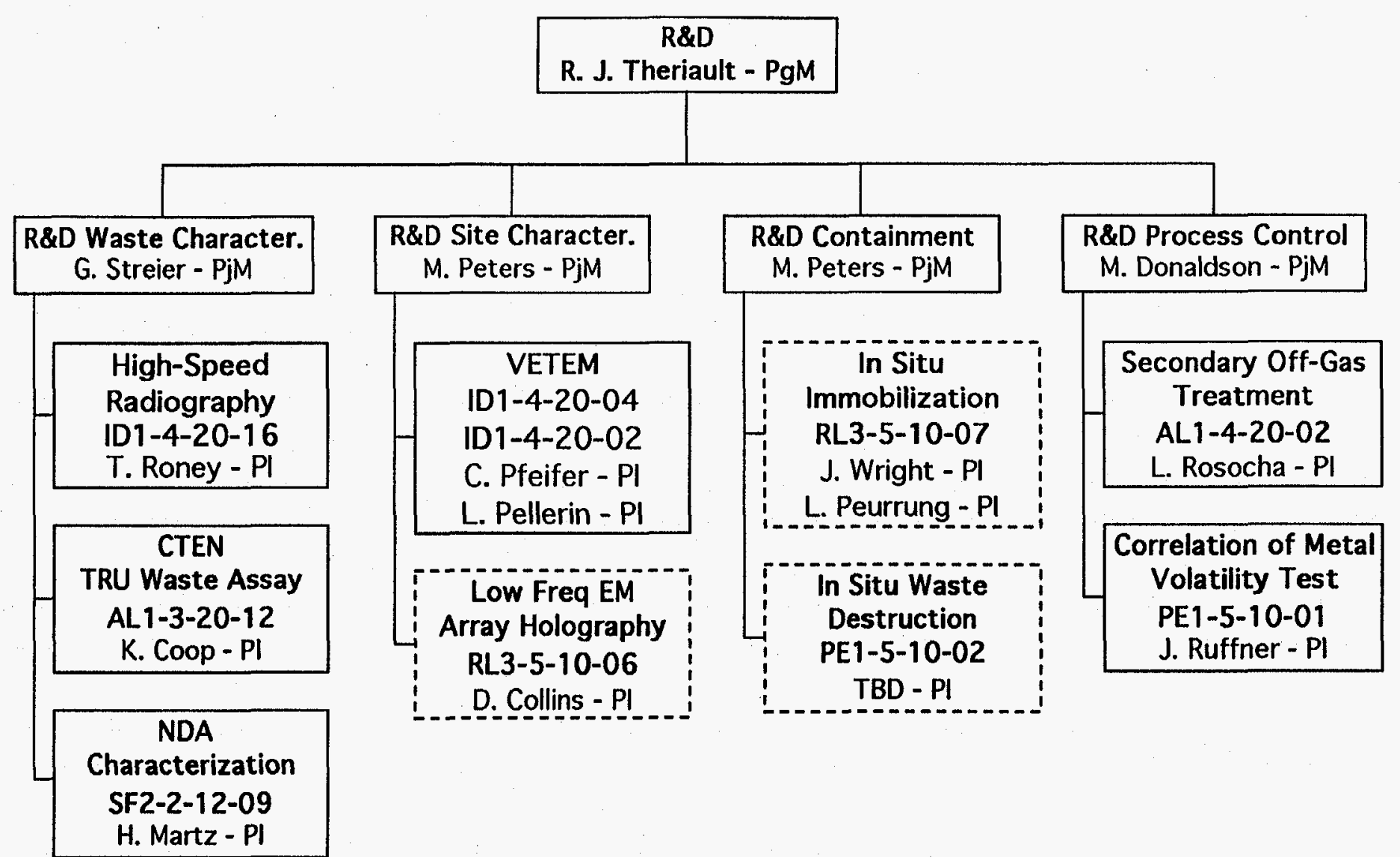

\section{KEY}

Technical Task Plan Title

Technical Task Plan Number

Principal Investigator

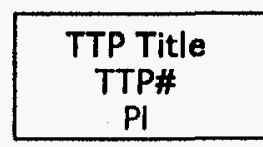

$\square$ TTP Funded for FY-95

$r-\cdots-$, TTP Not Funded for FY-95

Figure 5. Non-INEL R\&D demonstrations. 


\subsection{Office Research}

The three remaining BWID-sponsored projects include office research (paper studies and computer simulations) and technical review meetings. The following projects fall into this category: Radiological and Hazardous Material Measurement System, Site Characterization and Ground Penetrating Radar Consortium, and Treatment R\&D/Performance Testing.

PIs are responsible for following all requirements for training, emergency response, waste disposal, etc., defined for the facility in which the work is performed. No deployment support needs are expected. These studies are shown in Figure 6. 


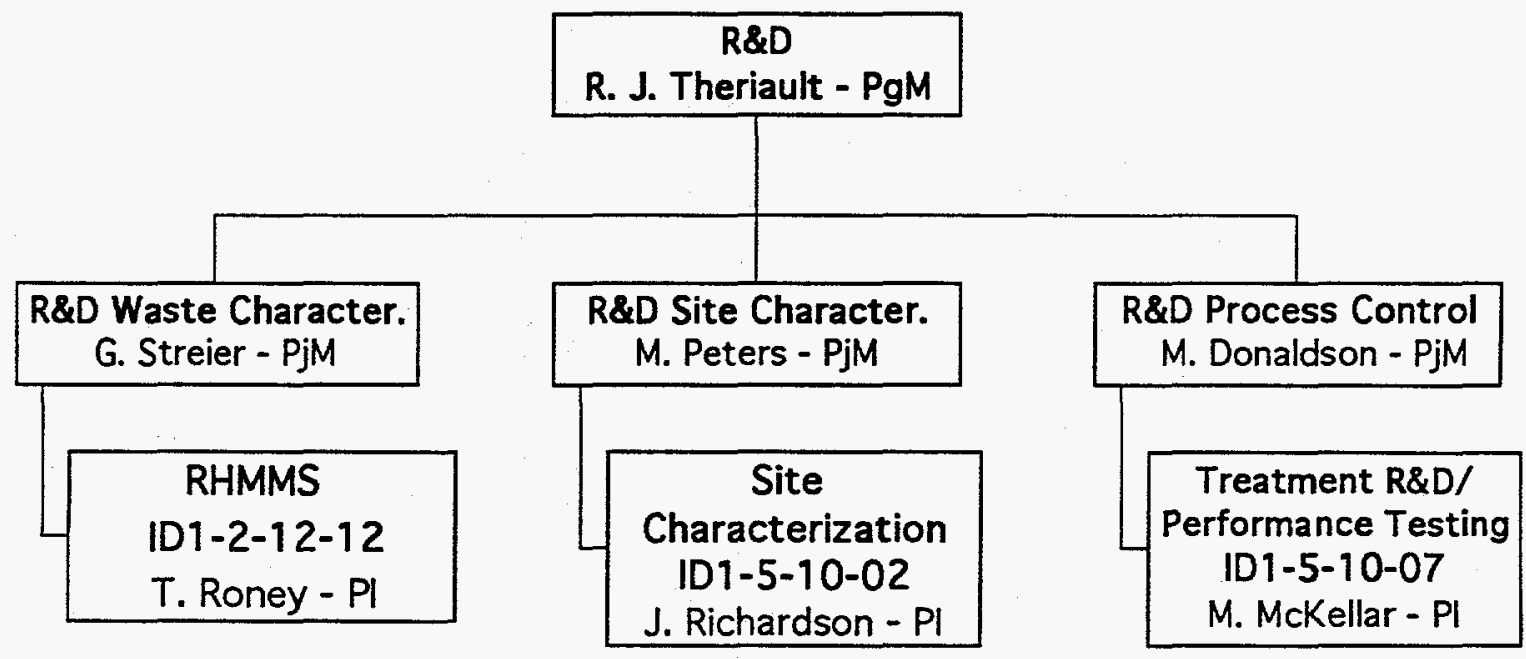

\section{KEY}

Technical Task Plan Title

Technical Task Plan Number

Principal Investigator

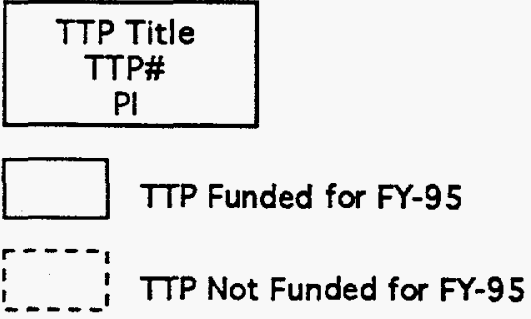

Figure 6. Office research. 


\section{PUBLIC OUTREACH}

BWID has established a public outreach strategy to educate the general public, elected representatives, and regulatory agencies about waste technology demonstrations. Presentations, media releases, interviews with media representatives, an open house, and an equipment display are among the mechanisms used in the outreach strategy.

\subsection{Media Releases}

During INEL demonstrations, BWID personnel will work with PIs to prepare media releases for the INEL Public Affairs Office. As appropriate, media tours may be organized. Any visits to the test sites during demonstrations will be designed to minimize or prevent impact on the demonstration. As results of the demonstrations become known, followup media releases will be prepared by BWID and the PI. Interviews between BWID or demonstration personnel and medial representatives may also be arranged through BWID and the INEL Public Affairs Office.

\subsection{Photographs and Video Records}

The BWID deployment manager will arrange for photographic and video coverage of the demonstrations. PIs must contact the BWID deployment manager at least six weeks prior to the demonstration for photography/video support. Photographic/video coverage, while not required by BWID, is strongly recommended to provide useful historical information for presentations, papers, and poster sessions about the technology, as well as for the Technology Development File. INEL photography will provide professional photographers for this task. Arrangements must be made well in advance to avoid schedule conflicts.

\subsection{Open House and Equipment Display}

An open house and equipment display is scheduled for August 1995. Presentations from DOE Headquarters, DOE Idaho Operations Office, private industry, local government, the media, DOE Program Planning and Technical Support Groups, and integrated demonstration and integrated program coordinators will be invited to attend

BWID will organize and mail invitations to the open house. PIs will be responsible for preparing a poster session and video presentation. Information may include a description of the technology, demonstration objectives, technology need, baseline technologies, demonstration results, and follow-on activities.

The equipment display will feature the equipment used for technology demonstrations. PIs will be responsible for transporting and setting up the equipment at University Place in Idaho Falls. PIs will also be responsible for providing personnel to explain technology and equipment features to attendees. BWID will provide equipment security by LITCO Physical Security. 


\subsection{Midyear Review}

The OTD will conduct a midyear review of technologies in March 1995 in Washington, D.C. The BWID midyear review will be held in February 1995 in Denver, Colorado. 


\section{SCHEDULES}

In this section, schedules are provided for the BWID Deployment Team activities, the INEL integrated field demonstration, INEL R\&D tests, and non-INEL R\&D tests. Paper studies are not addressed because all final reports will be submitted on or by September 30, 1995.

\subsection{BWID Deployment Team Activities Schedule}

Figure 7 shows the schedule for activities the deployment team is performing to support the technology demonstrations, tests, and evaluations. The schedule includes preparation activities such as obtaining and deploying generators, toilets, fire extinguishers, PPE, etc. In addition, the schedule shows containment structure installation and site restoration activities. The schedule also shows activities that are ongoing. For example, preparedness reviews are conducted to each project prior to field testing. Because these preparedness reviews are not held at the same time, a single schedule line is included spanning the range of reviews currently planned. Table 1 shows the deployment team schedule for technology assessments and preparedness reviews.

\subsection{Technology Test Schedule}

\subsubsection{INEL Integrated Field Demonstration Test Schedule}

Figure 8 shows the test schedule for projects participating in the INEL FY-95 integrated field demonstration. Project testing will occur at the NBRC located in Idaho Falls.

\subsubsection{INEL R\&D Test Schedule}

Figure 9 shows the test schedule for R\&D demonstrations to be performed at INEL facilities in FY-95.

\subsubsection{Non-INEL R\&D Test Schedule}

Figure 10 shows the schedule for R\&D demonstrations to be performed in FY-95 at locations other than the INEL. 


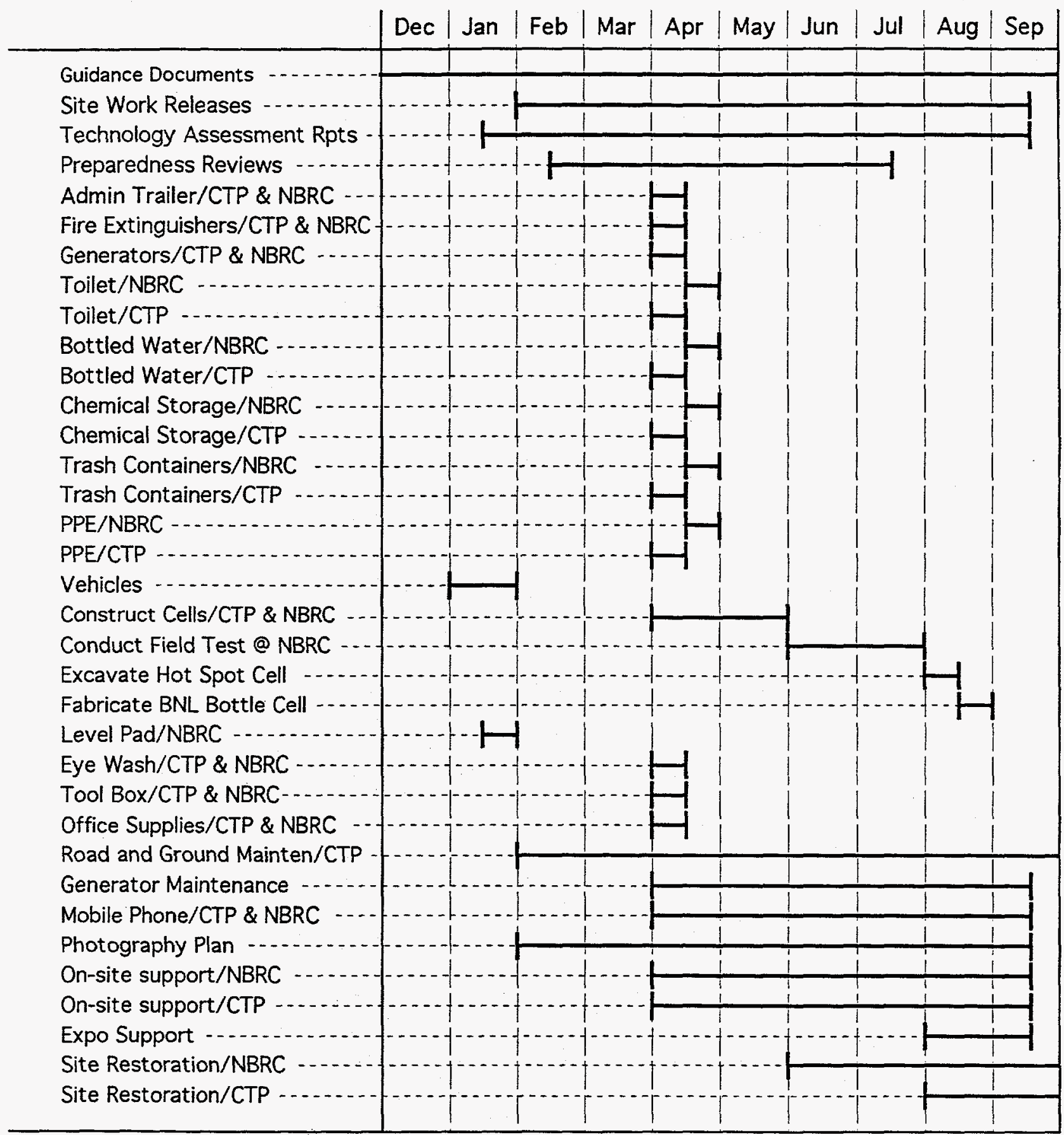

Figure 7. Deployment Team activities schedule. 
Table 1. Schedules for guidance and ESH\&Q plans.

\begin{tabular}{|c|c|c|c|}
\hline Report title & $\begin{array}{c}\text { Revision } \\
\text { draft due } \\
\text { date }\end{array}$ & $\begin{array}{l}\text { Final due } \\
\text { date }\end{array}$ & $\begin{array}{l}\text { Original } \\
\text { issue date }\end{array}$ \\
\hline $\begin{array}{l}\text { BWID TP\&SR Guidance, EGG-WTD-10266, } \\
\text { Rev. } 1\end{array}$ & a & b & April 1994 \\
\hline $\begin{array}{l}\text { BWID Test Goals and Objectives, } \\
\text { EGG-WTD-11112 }\end{array}$ & a & N/A & $\begin{array}{l}\text { January } \\
1994\end{array}$ \\
\hline BWID Test Plan Guidance, EGG-WTD-9800 & $03 / 01 / 95$ & $04 / 14 / 95$ & $\begin{array}{l}\text { January } \\
1994\end{array}$ \\
\hline $\begin{array}{l}\text { BWID Technology Evaluation Report } \\
\text { Guidance, EGG-WTD-10104, Rev. } 2\end{array}$ & $\mathbf{a}$ & N/A & $\begin{array}{l}\text { January } \\
1994\end{array}$ \\
\hline $\begin{array}{l}\text { BWID Project Management Plan, } \\
\text { EGG-WTD-11224 }\end{array}$ & $03 / 15 / 95$ & 9/31/95 & $\begin{array}{l}\text { February } \\
1994\end{array}$ \\
\hline $\begin{array}{l}\text { BWID Deployment Plan, EGG-WTD-11156 } \\
\text { (INEL-95/0089) }\end{array}$ & $01 / 27 / 95$ & 03/10/95 & May 1994 \\
\hline $\begin{array}{l}\text { BWID Commercialization Action Plans, } \\
\text { EGG-WTD-11252 }\end{array}$ & $\mathbf{a}$ & N/A & April 1994 \\
\hline $\begin{array}{l}\text { BWID Stakeholder Involvement Model, } \\
\text { EGG-WTD-11191 }\end{array}$ & a & N/A & April 1994 \\
\hline Quality Program & $\begin{array}{l}\text { Company } \\
\text { Quality } \\
\text { Manual. }\end{array}$ & $\begin{array}{l}\text { Company } \\
\text { Quality } \\
\text { Manual }\end{array}$ & N/A \\
\hline $\begin{array}{l}\text { ESH\&Q for the BWID Program, } \\
\text { EGG-WTD-11216 }\end{array}$ & $05 / 15 / 95$ & $06 / 02 / 95$ & May 1994 \\
\hline BWID Waste Minimization Plan & $03 / 17 / 95$ & $06 / 16 / 95$ & May 1992 \\
\hline BWID Program Manual & a & N/A & $\begin{array}{l}\text { February } \\
1994\end{array}$ \\
\hline $\begin{array}{l}\text { BWID Integrated Test Plan, } \\
\text { EGG-WTD-11440 (INEL-94/0027) }\end{array}$ & $04 / 19 / 95$ & $05 / 01 / 95$ & New \\
\hline
\end{tabular}




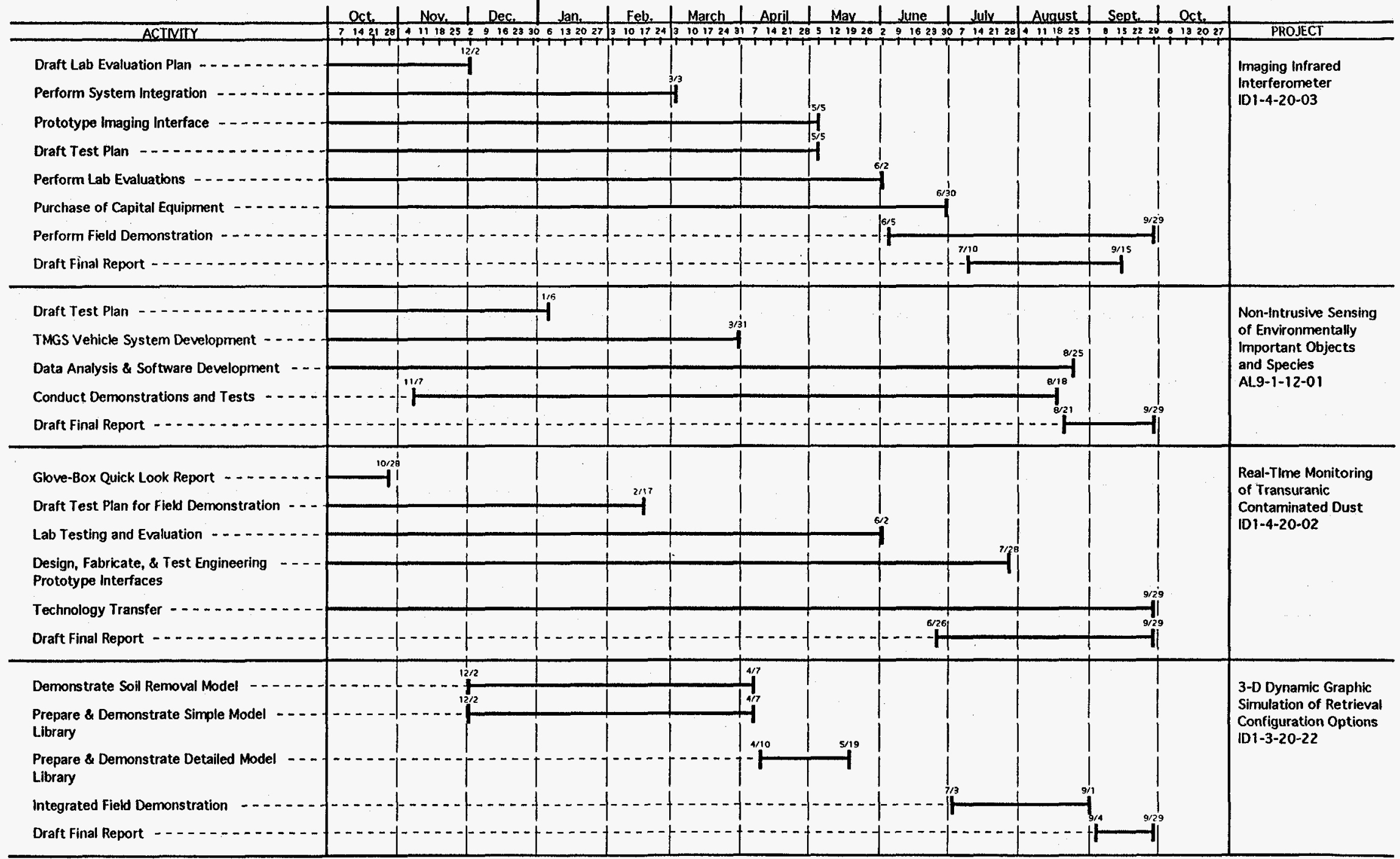

Figure 8. Schedules of INEL into grated field demonstration technologies. 
1994

1995

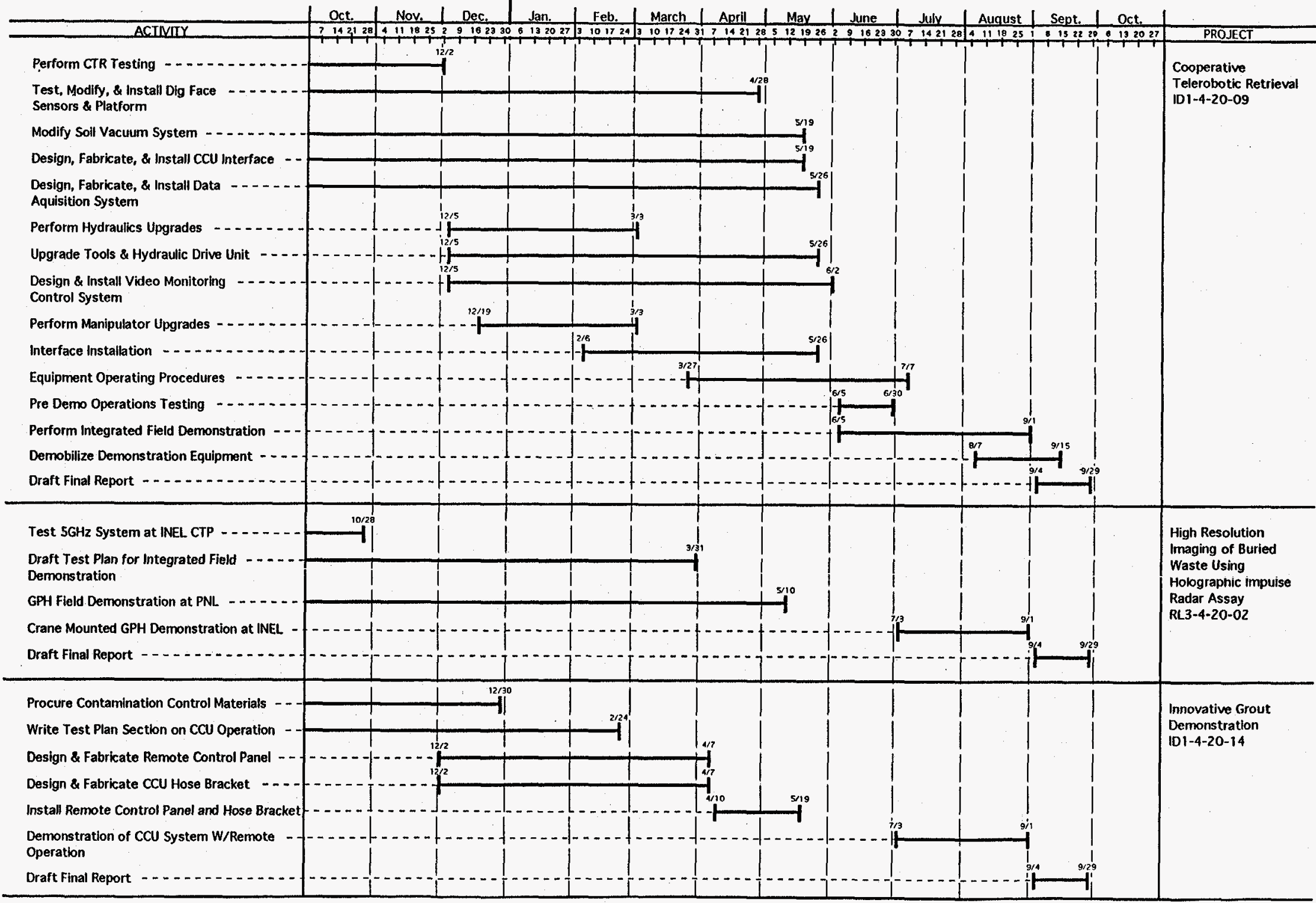

Figure 8. (continued). 


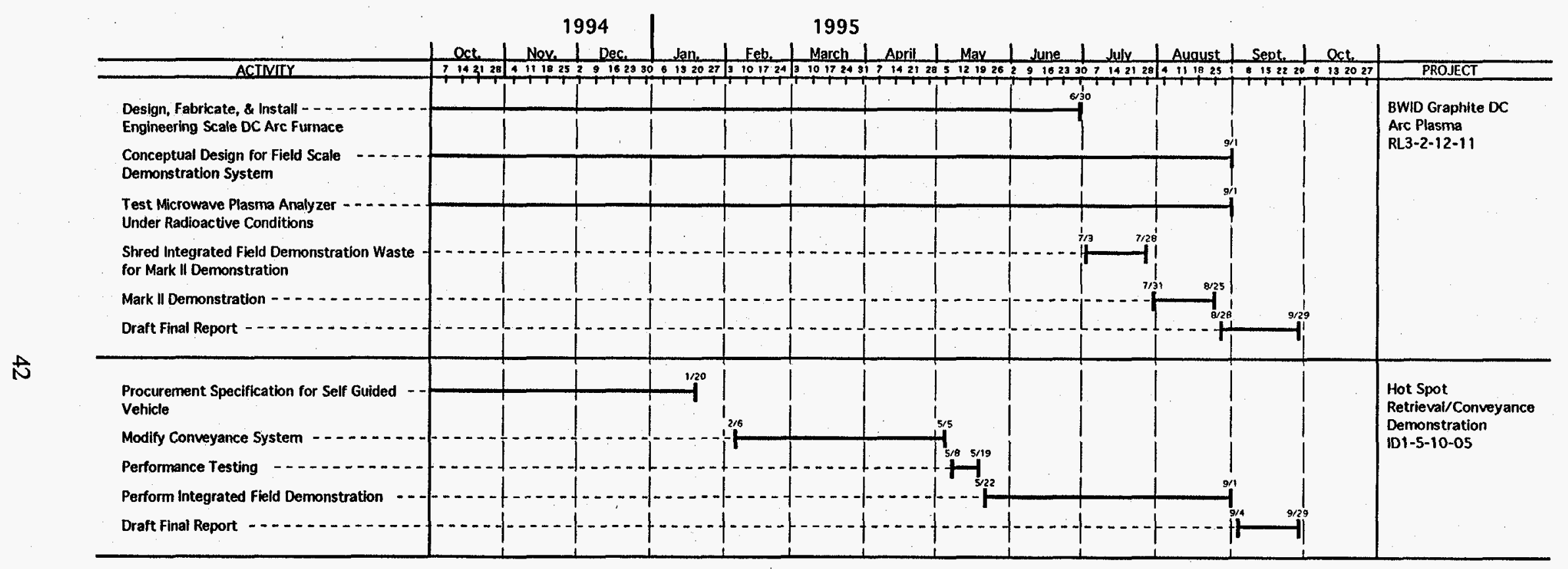

Figure 8. (continued). 


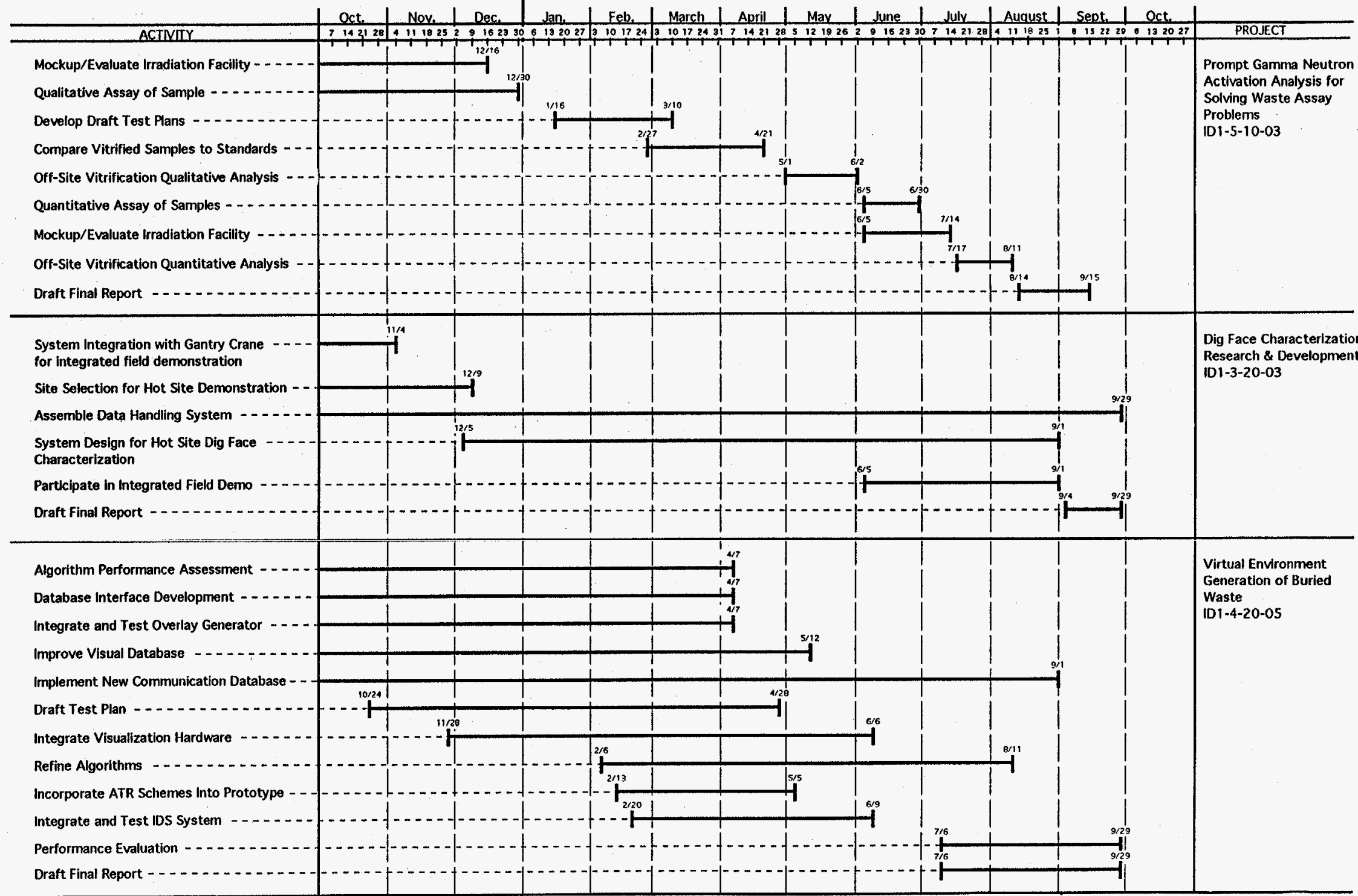

Figure 9. Schedules for INEL R\&D technologies. 


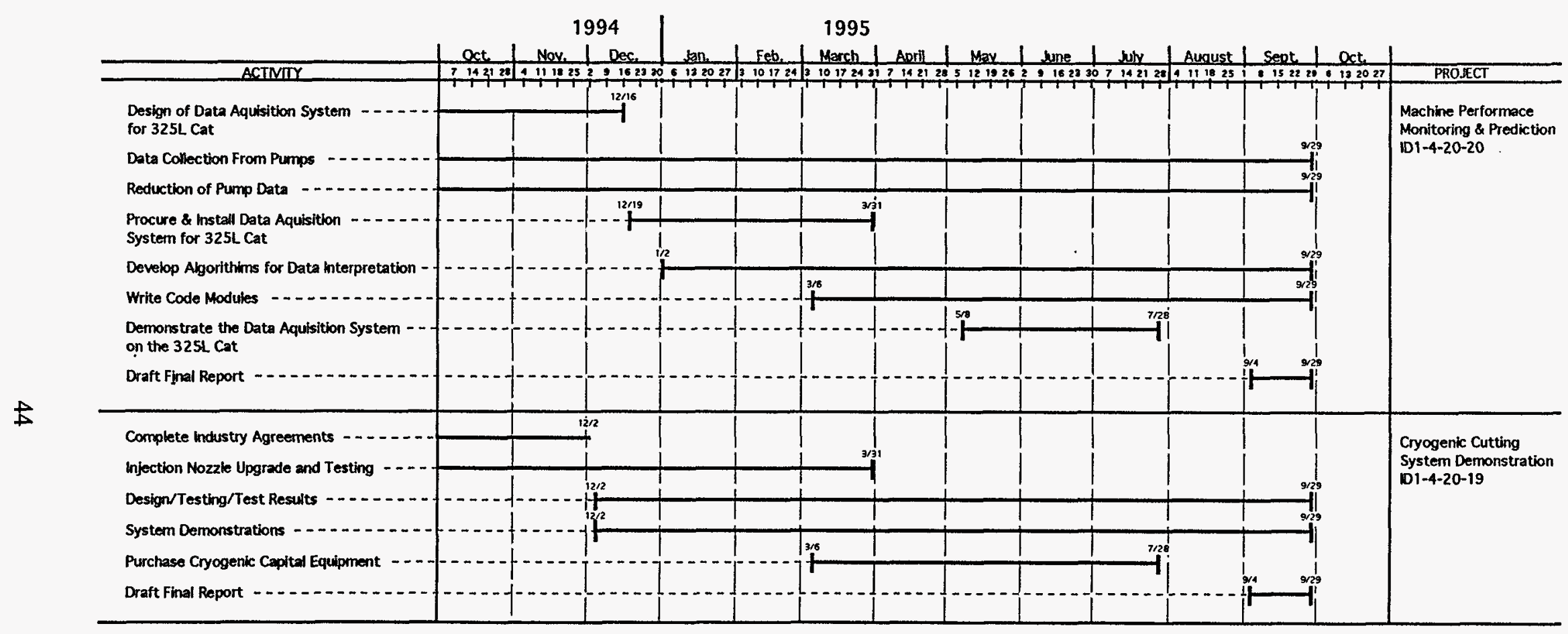

Figure 9. (continued). 


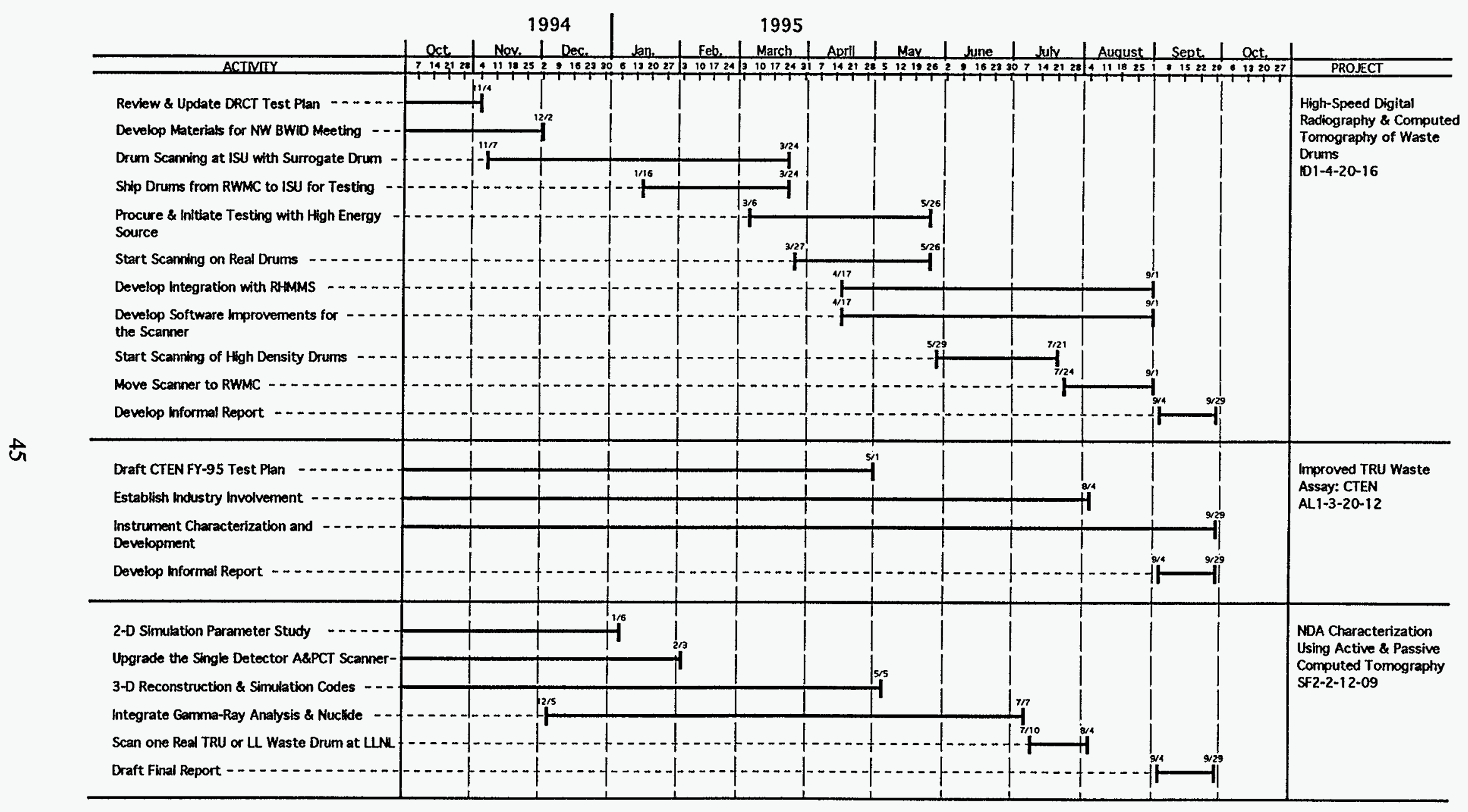

Figure 10. Schedules for non-INEL R\&D technologies. 


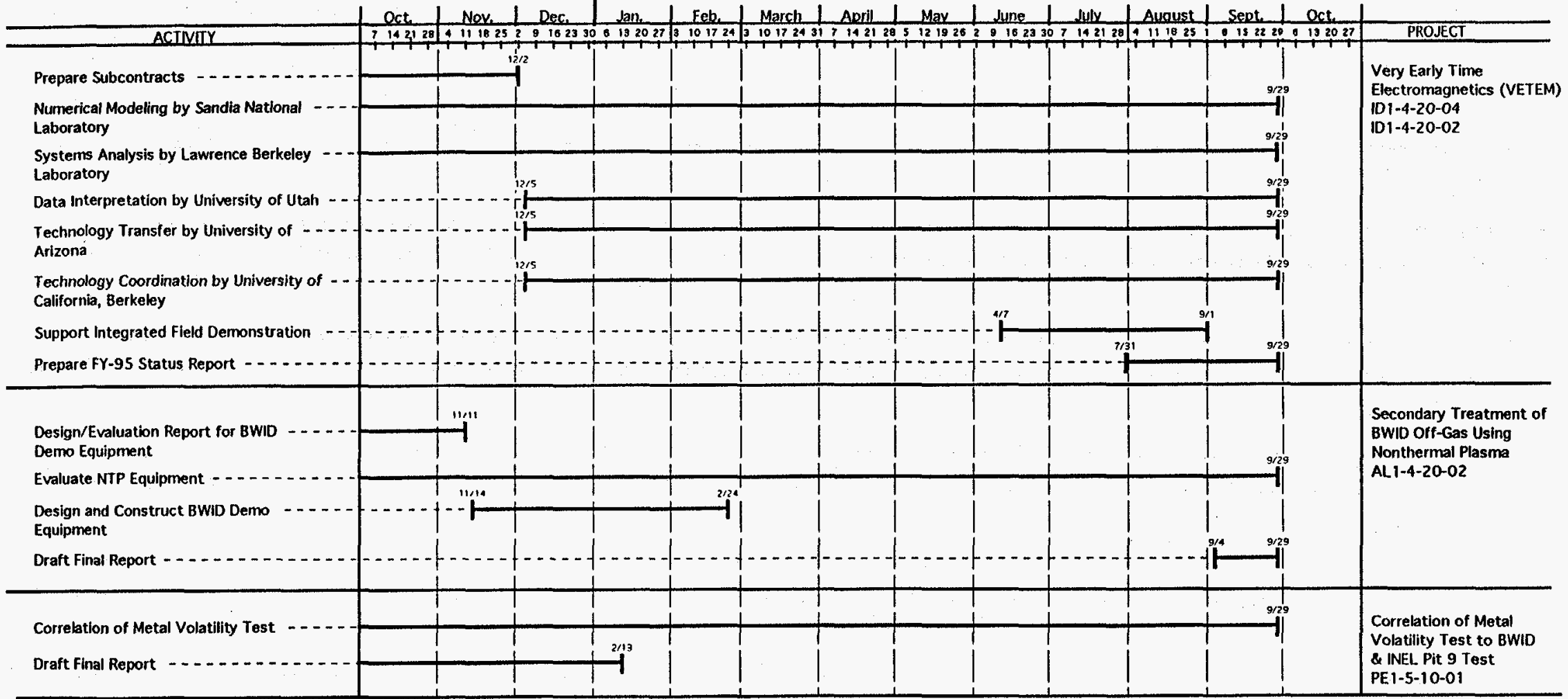

Figure 10. (continued). 